\title{
Organic composition and source apportionment of fine aerosol at Monterrey, Mexico, based on organic markers
}

\author{
Y. Mancilla ${ }^{1}$, A. Mendoza ${ }^{1}$, M. P. Fraser ${ }^{2}$, and P. Herckes ${ }^{3}$ \\ ${ }^{1}$ School of Engineering and Sciences, Tecnológico de Monterrey, Monterrey, Mexico \\ ${ }^{2}$ School of Sustainable Engineering and the Built Environment, Arizona State University, Tempe, Arizona, USA \\ ${ }^{3}$ School of Molecular Sciences, Arizona State University, Tempe, Arizona, USA \\ Correspondence to: Y. Mancilla (y.mancilla@itesm.mx)
}

Received: 11 April 2015 - Published in Atmos. Chem. Phys. Discuss.: 2 July 2015

Revised: 9 January 2016 - Accepted: 11 January 2016 - Published: 26 January 2016

\begin{abstract}
Primary emissions from anthropogenic and biogenic sources as well as secondary formation are responsible for the pollution levels of ambient air in major urban areas. These sources release fine particles into the air that negatively impact human health and the environment. Organic molecular markers, which are compounds that are unique to specific $\mathrm{PM}_{2.5}$ sources, can be utilized to identify the major emission sources in urban areas. In this study, 43 representative $\mathrm{PM}_{2.5}$ samples, for both daytime and nighttime periods, were built from individual samples collected in an urban site of the Monterrey metropolitan area (MMA) during the spring and fall of 2011 and 2012. The samples were analyzed for organic carbon, elemental carbon, and organic molecular markers. Several diagnostic tools were employed for the preliminary identification of emission sources. Organic compounds for eight compound classes were quantified. The $n$-alkanoic acids were the most abundant, followed by $n$-alkanes, wood smoke markers, and levoglucosan/alkenoic acids. Polycyclic aromatic hydrocarbons (PAHs) and hopanes were less abundant. The carbon preference index $(0.7-2.6)$ for $n$-alkanes indicates a major contribution of anthropogenic and mixed sources during the fall and the spring, respectively. Hopanes levels confirmed the contribution from gasoline and diesel engines. In addition, the contribution of gasoline and diesel vehicle exhaust was confirmed and identified by the PAH concentrations in $\mathrm{PM}_{2.5}$. Diagnostic ratios of PAHs showed emissions from burning coal, wood, biomass, and other fossil fuels. The total PAHs and elemental carbon were correlated $\left(r^{2}=0.39-0.70\right)$ across the monitoring periods, reinforcing that motor vehicles are the major contributors of PAHs. Cholesterol levels remained constant during the spring and
\end{abstract}

fall, showing evidence of the contribution of meat-cooking operations, while the isolated concentrations of levoglucosan suggested occasional biomass burning events. Finally, source attribution results obtained using the CMB (chemical mass balance) model indicate that emissions from motor vehicle exhausts are the most important, accounting for the $64 \%$ of the $\mathrm{PM}_{2.5}$, followed by meat-cooking operations with $31 \%$ The vegetative detritus and biomass burning had the smallest contribution ( $2.2 \%$ of the $\mathrm{PM}_{2.5}$ ). To our knowledge, this is only the second study to explore the organic composition and source apportionment of fine organic aerosol based on molecular markers in Mexico and the first for the MMA. Particularly molecular marker were quantified by solvent extraction with dichloromethane, derivatization, and gas chromatography with mass spectrometry (GC/MS).

\section{Introduction}

Fine organic aerosol (OA) has a major role in environmental and human health impacts (Peng et al., 2009). Some researchers have recently estimated that fine OA constitutes $23-38 \%$ of the $\mathrm{PM}_{2.5}$ mass in urban areas (Qin et al., 2006; Viana et al., 2006; Duan et al., 2007; Upadhyay et al., 2011). In addition, OA along with elemental carbon (EC) can account for up to $31-57 \%$ of the $\mathrm{PM}_{2.5}$ mass (Duan et al., 2007; Upadhyay et al., 2011; Martínez et al., 2012).

Atmospheric fine OA is a complex mixture of hundreds of organic compounds that are directly emitted or are generated by atmospheric chemical processes. Many of these organic compounds are toxic or carcinogenic (Spurny, 2000; 
Pope et al., 2002), but can be useful as markers to identify the source of the aerosols being measured at a specific site. Organic markers that have been used in the past include levoglucosan, cholesterol, nicotine, $n$-alkanes, hopanes (pentacyclic triterpenes), and polycyclic aromatic hydrocarbons (PAHs). Levoglucosan is a pyrolysis decomposition and combustion product of cellulose; therefore, it can be used as a tracer for biomass burning sources (Fraser and Lakshmanan, 2000; Robinson et al., 2006a; Alves et al., 2011; Gonçalves et al., 2011). Cholesterol and nicotine are good markers for meat-cooking operations (Rogge et al., 1991; Schauer et al., 2001b; Robinson et al., 2006b) and cigarette smoke (Eatough et al., 1989; Hildemann et al., 1991; Rogge et al., 1994; Kavouras et al., 1998), respectively. Hopanes are biomarkers of fuel oil combustion, coal combustion, and lubricants, and are useful to identify engine emissions (Rogge et al., 1993a; Oros and Simoneit, 2000; Simoneit et al., 2004; Schnelle-Kreis et al., 2005). PAHs are semi-volatile compounds formed from incomplete fossil fuel combustion processes (Rogge et al., 1993a; Marr et al., 2004; Sklorz et al., 2007). Finally, $n$-alkanes are indicators of fossil fuel utilization and biogenic emissions (Simoneit et al., 2004; Young and Wang, 2002). Additional details about specific organic markers and their emission sources can be found elsewhere (Simoneit et al., 1991; Simoneit, 1999; Lin et al., 2010; Blanchard et al., 2014).

The diagnostic ratios between homologues in series of biomolecules are another feature used to identify the origin of fine OA are. For $n$-alkanes and alkanoic acids, the odd- and even-carbon preferences are indicators of biogenic sources (Tsapakis et al., 2002). A lack of carbon preference is indicative of fossil sources. For the case of PAHs, some ratios can be used to identify emissions from fossil fuel combustion (Zhang et al., 2005).

Source apportionment studies based on organic molecular markers have accomplished a better understanding of the emission sources in urban areas. This approach considers two main principles: (1) that organic molecular markers are present in relatively high concentrations in emissions from a specific source and in lower concentrations in the remaining sources, and (2) that they react slowly enough in the atmosphere to be conserved during transport from the source to the observation/receptor site (Schauer et al., 1996; Lin et al., 2010). The use of organic molecular markers in the last decade has proven to be a powerful method to identify and attribute emission sources in urban areas (Alves et al., 2001; Fraser et al., 2003; Abas et al., 2004; Kalaitzoglou et al., 2004; Zheng et al., 2005; Feng et al., 2006; Huang et al., 2006; Li et al., 2006; Park et al., 2006; Alves et al., 2007; Chow et al., 2007; Ke et al., 2007; Stone et al., 2008; Amador-Muñoz et al., 2010; Yin et al., 2010; Pietrogrande et al., 2011; Perrone et al., 2012; Giri et al., 2013; Villalobos et al., 2015; Watson et al., 2015; Zheng et al., 2015). In spite of recent research interest on organic molecular markers for source apportionment, the application of this approach started in the 1980s (Simoneit, 1985, 1986; Eatough et al., 1989; Simoneit and Mazurek, 1989) and continued in the 1990s (Simoneit et al., 1990, 1991; Schauer et al., 1996; Simoneit, 1999; Schauer and Cass, 2000), especially with the development of organic source profiles for primary emission sources (Rogge et al., 1991, 1993a, b, c, 1994, 1997; Fraser et al., 1999; Schauer et al., 1999) and alternative receptor models (Paatero 1997; Wold et al., 2001). Furthermore, improved source apportionment methods have been developed (Chen et al., 2011; Kelly et al., 2013; Watson et al., 2015), while other methods have been suggested to be dropped as receptor models (Hopke, 2015). More detailed information about source apportionment methods can be found elsewhere (Reff et al., 2007; Viana et al., 2008; Lin et al., 2010; Nozière et al., 2015).

For the Monterrey metropolitan area (MMA), the third largest urban center of Mexico, there is a growing concern to determine the emission sources of fine OA. It was recently determined that fine OA accounts for $36-71 \%$ of $\mathrm{PM}_{2.5}$ mass in this urban center (Mancilla et al., 2015). Previously, Martínez et al. (2012) estimated an OA fraction of $\sim 40 \%$ of the $\mathrm{PM}_{2.5}$ for the MMA. According to a recent tunnel study, $\mathrm{PM}_{2.5}$ emissions from gasoline-powered vehicles (one of the major emission sources in the MMA) contain as much as $55 \%$ of carbonaceous material (Mancilla and Mendoza, 2012). To date, only one study has addressed the chemical characterization of fine OA in the MMA, but it focused exclusively on the levels of PAHs (González-Santiago, 2009). More importantly, the present study would be the second of this kind in Mexico and the first one for the MMA; previously, Stone et al. (2008) reported an evaluation of molecular organic markers for source apportionment at Mexico City. This city has a temperate and wet climate, while the MMA has a dry and extreme climate with scarce rains. It is well known that climate conditions can affect the air quality in urban areas. Extreme climates, including high temperatures, could increase the concentrations of air pollutants. For example, warm and dry climates promote photochemical reactions in the atmosphere producing secondary OA. The unique geography and the changeable climate as well as the typical industries of the region make the MMA unique and different from other Mexican cities.

\section{Methodology}

\subsection{Sampling site}

The MMA has a population of 4.2 million inhabitants (INEGI, 2011) and is considered the largest urban area in northeastern Mexico and the third-largest urban center in the country. The MMA is composed of 12 municipalities that overall cover an area of $6680 \mathrm{~km}^{2}$ (SEDESOL et al., 2007), as shown in Fig. 1. The MMA has a vehicular fleet of 1.7 million vehicles (INEGI, 2010) with a composition of approx- 


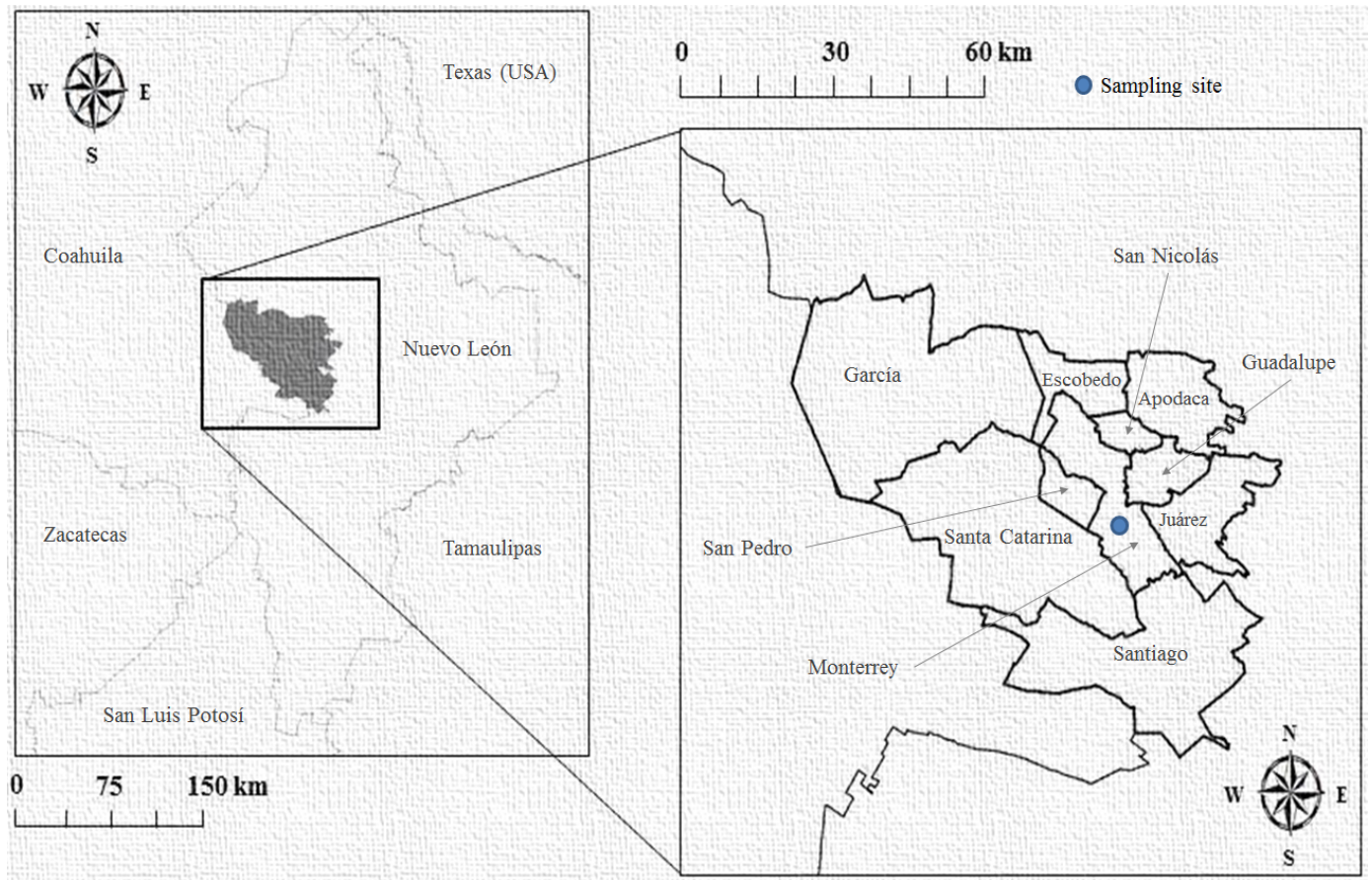

Figure 1. Location and municipalities of the Monterrey metropolitan area (MMA); the sampling site was set up in the downtown.

imately $73 \%$ gasoline-powered vehicles (passenger cars), $25 \%$ diesel-powered vehicles (buses and trucks) and $3 \%$ motorcycles. In addition, industrial activity in the MMA is dominated by manufacturing industries, construction and electricity, transport, restaurants, and other local services. The MMA has a network of air quality monitoring stations (Sistema Integral de Monitoreo Ambiental, SIMA). For this study, $\mathrm{PM}_{2.5}$ samples were collected at only one site placed in the facilities of the downtown monitoring station of the SIMA network $\left(25^{\circ} 40^{\prime} 32^{\prime \prime} \mathrm{N}, 100^{\circ} 20^{\prime} 18^{\prime \prime} \mathrm{W}\right), 556$ m.a.s.l. (meters above sea level). The sampling site is affected mainly by traffic and emissions from a wide range of industrial activities (e.g., steel and cement production). The vegetation around the sampling site includes dispersed and scarce grass, shrubs, and street tree systems in the immediate vicinity as well as in the periphery. The sampling site selection was based on coefficients of divergence (COD) analysis using the $24 \mathrm{~h}$ average $\mathrm{PM}_{2.5}$ concentrations recorded in 2009 by the SIMA network. Details about this analysis can be found elsewhere (Mancilla et al., 2015).

\subsection{Sampling periods and instruments}

The samples were collected during the spring and fall of 2011 and 2012 (Table 1). For every sampling day, two consecutive $12 \mathrm{~h}$ samples were taken to obtain information for daytime and nighttime periods. The daytime sampling was performed from 06:00 to 18:00 (local time), while nighttime samples were collected from 18:00 to 06:00 the next day. For the spring and fall 2011 campaigns, sampling periods were performed on alternate days. For example, for the spring of 2011, the first sampling day was on 28 May, the second on 30 May, and so on. For the campaigns of 2012, both were conducted for 14 consecutive sampling days.

Carbonaceous aerosol samples were collected using highvolume filter-based instruments with a $\mathrm{PM}_{2.5}$ inlet (TE6001-2.5, Tisch Environmental Inc.), operating at a flow of $1.13 \mathrm{~m}^{3} \mathrm{~min}^{-1}$. The flow rates for the high-volume samplers were calibrated at the start and end of each monitoring campaign. For each high-volume sampler, the calibration was carried out using a calibration orifice (NIST Traceable Calibration Certificate). The samplers were mounted on the rooftop of the monitoring station $3 \mathrm{~m}$ above the ground. One high-volume sampler was used for each campaign, except for the campaign of fall 2012, in which two high-volume samplers were deployed and operated simultaneously to collect pairs of samples for each diurnal and nighttime sampling period. Fine particles were collected on 8 in. $\times 10$ in. quartz microfiber filters (Whatman QMA). Filters were previously pre-fired for $8 \mathrm{~h}$ at $600^{\circ} \mathrm{C}$ in a furnace to remove residual carbon and stored in baked aluminum foil within sealed plastic bags $\left(\right.$ Ziploc $\left.^{\circledR}\right)$ until they were used. After sampling, loaded 8 in. $\times 10$ in. filters were stored in tall 8 oz. glass jars (VWR, IR221-0250). Loaded filters were placed in a cooler with blue ice for immediate transport from the sampling site to the laboratory. All loaded filters were stored in a freezer at $-20^{\circ} \mathrm{C}$ to prevent the evaporation of volatile compounds until they were analyzed. A total of 111 samples and 10 field blanks were collected throughout the study. 
Table 1. Monitoring experiments conducted for this study.

\begin{tabular}{lllll}
\hline Campaign & Period & Sampling days & Samples & Field blanks \\
\hline Spring 2011 & 28 May to 11 June & $7^{*}$ & 14 & 2 \\
Fall 2011 & 22 October to 3 November & $7^{*}$ & 14 & 2 \\
Spring 2012 & 6 to 19 June & 14 & 27 & 2 \\
Fall 2012 & 13 to 26 October & 14 & 56 & 4 \\
\hline
\end{tabular}

* Non-consecutive days.

\subsection{Ambient measurements}

For spring 2011, analyses for each $12 \mathrm{~h}$ sample were carried out as discussed by Mancilla et al. (2015). Even though the samples collected for spring 2011 exhibited high levels of OC, some concentrations for different organic compounds of interest were low $\left(0.03\right.$ to $\left.0.16 \mathrm{ng} \mathrm{m}^{-3}\right)$. In addition, the OC concentrations for the last three campaigns (fall 2011, spring 2012, and fall 2012) were on average up to $35 \%$ lower than OC concentrations of spring 2011. Based on these findings, composites were formed for the last three campaigns to ensure higher levels of collected mass used to identify the organic molecular markers. Weekday-weekend and daytimenighttime differences of fine OC levels were investigated and considered in order to pool sample filters into weekday and weekend composites for the last three campaigns (Mancilla et al., 2015). Each composite included only daytime or nighttime samples collected during weekdays (MonThu) or weekend (Fri-Sun). Sample groups for composites varied from two to six sample filters. Thereafter, the number of individual samples (or filters) was reduced from 111 to 43 representative samples. The composites made for this study are described in Table 2.

Solvent-extractable molecular markers were quantified using gas chromatography mass spectrometry (GC/MS) using dichloromethane (DCM) and methanol (MeOH) (high purity, $99.9 \%$, Fisher Scientific). Filters were spiked with $50 \mu \mathrm{L}$ of the following deuterated internal standards (Sigma Aldrich): $n$-hexadecane-d34, $n$-hexatriacontane-d74, $n$-eicosane-d42, $n$-triacontane-d62, vanillin-d3, benzophenone-d5, chrysene$\mathrm{d} 12$, dibenz(a,h)anthracene-d14, naphthalene-d8, pyrened10, benzo(e)pyrene-d12, coronene-d12, decanoic acid-d19, palmitic acid-d31, stearic acid-d35, levoglucosan-13c6, and cholesterol-d6. Each individual filter or sample composite was extracted three times with DCM. During each extraction, enough DCM was added and then ultrasonic agitation was applied for $20 \mathrm{~min}$ using a sonicator $\left(\right.$ Bransonic $^{\circledR}$, model 5510R-DTH). The extracts were combined and then concentrated by evaporation under a gentle flow of ultra-highpurity nitrogen until the extract reached a volume of $\sim 5 \mathrm{~mL}$. The extracts were filtered through a pre-fired quartz filter, subsequently reduced in volume to $250 \mu \mathrm{L}$, and then separated into three fractions. One fraction was a direct portion of the $250 \mu \mathrm{L}$ extract for direct analysis by GC/MS, and the other two fractions were used for chemical derivatizations. One fraction was methylated using diazomethane $\left(\mathrm{CH}_{2} \mathrm{~N}_{2}\right)$ to convert carboxylic acids to their respective methyl esters. Another fraction was silylated using a combination of BSTFA (N,O-bis(trimethylsilyl)trifluoroacetamide) and TMCS (trimethylchlorosilane) to convert sterols and sugars to their respective trimethylsilyl esters. For methylation, $50 \mu \mathrm{L}$ of a $\mathrm{CH}_{2} \mathrm{~N}_{2}$ solution was combined in a vial with $50 \mu \mathrm{L}$ of extract. For the silylation, $50 \mu \mathrm{L}$ of BSTFA+TMCS (molar ratio 99:1) was combined with $50 \mu \mathrm{L}$ sample extract. Then, the mixture was allowed to react for $3 \mathrm{~h}$ at $65^{\circ} \mathrm{C}$. The quantification and identification of organic compounds was based on comparisons with authentic standards, retention times, literature mass spectra, and fragmentation patterns using HP ChemStation. A detailed description of the extraction and analysis procedures as well as the chromatograph and column used can be found in Brown et al. (2002).

\subsection{Molecular diagnostic ratios}

To investigate the origin of fine organic aerosols, the following diagnostic ratios were used.

\subsubsection{Carbon preference index (CPI)}

The CPI is an indicator of the measure of odd- or even-carbon homologues series of organic compounds within a sample. Based on several studies (Abas and Simoneit, 1996; Tsapakis et al., 2002; Harrad et al., 2003), the CPI for $n$-alkanes (odd to even ratio) was calculated as

$\mathrm{CPI}=\frac{\sum\left(C_{17} \text { to } C_{33}\right)}{\sum}\left(C_{16}\right.$ to $\left.C_{32}\right)$,

and that for $n$-alkanoic acids (even to odd ratio) as

$\mathrm{CPI}=\frac{\sum\left(C_{10} \text { to } C_{32}\right)}{\sum\left(C_{11} \text { to } C_{31}\right)}$.

The CPI is an important indicator that is used to determine whether emissions come from natural or anthropogenic sources. For both $n$-alkanes and $n$-alkanoic acids, values of CPI $>1$ indicate that hydrocarbons and carboxylic acids are emitted from natural sources. In contrast, values of $\mathrm{CPI} \leq 1$ (or close to 1) indicate that they are emitted from anthropogenic sources (Gogou et al., 1996; Alves et al., 2001; Gelencsér, 2004). 
Table 2. Characteristics of individual and composite samples for each monitoring campaign. Values for $\mathrm{PM}_{2.5}$ are the averages obtained from the SIMA network. OC concentration values are the average values reported by Mancilla et al. (2015). SD represents standard deviation, I indicates that the dates included were analyzed individually, $\mathrm{C}$ indicates that the dates included were pooled to form a composite, $\mathrm{D}$ represents daytime sampling, $\mathrm{N}$ represents nighttime sampling, 1 refers to weekday sampling, and 2 refers to weekend sampling.

\begin{tabular}{|c|c|c|c|c|c|c|c|}
\hline \multirow[t]{2}{*}{ Campaign } & \multirow[t]{2}{*}{ Description } & \multirow[t]{2}{*}{ Dates included } & \multicolumn{2}{|c|}{$\mathrm{PM}_{2.5}$} & \multicolumn{3}{|c|}{$\mathrm{OC}$} \\
\hline & & & $\left(\mu \mathrm{g} \mathrm{m}^{-3}\right)$ & SD & & $\left(\mu \mathrm{g} \mathrm{m}^{-3}\right)$ & SD \\
\hline \multirow[t]{4}{*}{ Spring 2011} & ID1 & 30 May, 1, 9, 11 Jun & 20.3 & 8.7 & & 8.2 & 2.7 \\
\hline & ID2 & 28 May, 3, 5 Jun & 22.5 & 15.1 & & 10.7 & 5.7 \\
\hline & IN1 & 30 May, 1, 9, 11 Jun & 25.1 & 10.2 & & 6.3 & 1.5 \\
\hline & IN2 & 28 May, 3, 5 Jun & 31.7 & 22.6 & & 8.5 & 4.3 \\
\hline \multirow[t]{6}{*}{ Fall 2011} & CD1 & 24 Oct, $1 \mathrm{Nov}$ & 18.5 & 3.2 & & 8.7 & 1.6 \\
\hline & CD1 & 26 Oct, 3 Nov & 18.1 & 12.4 & & 8.2 & 5.4 \\
\hline & CN1 & 24 Oct, 1 Nov & 13.5 & 1.6 & & 4.7 & 0.3 \\
\hline & $\mathrm{CN} 1$ & 26 Oct, 3 Nov & 12.9 & 9.4 & & 5.5 & 2.5 \\
\hline & $\mathrm{CD} 2$ & $22,28,30 \mathrm{Oct}$ & 20.8 & 11.6 & & 9.3 & 3.3 \\
\hline & $\mathrm{CN} 2$ & $22,28,30 \mathrm{Oct}$ & 15.1 & 6.1 & & 6.7 & 2.1 \\
\hline \multirow[t]{11}{*}{ Spring 2012} & CD1 & 11,12 Jun & 17.1 & 3.7 & & 7.6 & 2.5 \\
\hline & CD1 & 13, 14 Jun & 19.3 & 1.7 & & 6.2 & 0.6 \\
\hline & CD1 & 18, 19 Jun & 12.6 & 0.7 & & 5.1 & 0.9 \\
\hline & CD1 & 6, 7 Jun & 18.3 & 2.0 & & 8.8 & 1.0 \\
\hline & CN1 & 11,12 Jun & 20.3 & 0.5 & & 4.3 & 0.8 \\
\hline & CN1 & 13, 14 Jun & 15.2 & 0.1 & & 3.3 & 0.1 \\
\hline & CN1 & $18,6,7$ Jun & 9.3 & 1.5 & & 4.0 & 0.8 \\
\hline & $\mathrm{CD} 2$ & $8,9,10$ Jun & 18.4 & 3.7 & & 8.3 & 0.7 \\
\hline & $\mathrm{CD} 2$ & $15,16,17$ Jun & 10.7 & 2.2 & & 4.6 & 0.6 \\
\hline & $\mathrm{CN} 2$ & $8,9,10$ Jun & 18.8 & 6.6 & & 5.3 & 1.0 \\
\hline & $\mathrm{CN} 2$ & 15, 16, 17 Jun & 9.3 & 3.1 & - & 2.8 & $0.6-$ \\
\hline \multirow[t]{12}{*}{ Fall 2012} & $\mathrm{CD} 2$ & $13,14,27$ Oct & 15.8 & 2.9 & & 9.3 & 1.3 \\
\hline & $\mathrm{CN} 2$ & $13,14,28$ Oct & 8.9 & 2.7 & & 6.8 & 1.1 \\
\hline & CD1 & 15,16 Oct & 17.6 & 4.1 & & 10.1 & 3.1 \\
\hline & CN1 & 15,16 Oct & 23.4 & 11.4 & & 11.4 & 3.9 \\
\hline & CD1 & 17,18 Oct & 17.6 & 11.9 & & 13.7 & 6.2 \\
\hline & CN1 & 17,18 Oct & 13.4 & 2.4 & & 8.7 & 1.9 \\
\hline & $\mathrm{CD} 2$ & $19,20,21 \mathrm{Oct}$ & 29.7 & 5.5 & & 10.9 & 2.1 \\
\hline & $\mathrm{CN} 2$ & $19,20,21 \mathrm{Oct}$ & 23.1 & 1.1 & & 6.6 & 2.1 \\
\hline & CD1 & 22,23 Oct & 23.6 & 3.9 & & 8.1 & 0.2 \\
\hline & CN1 & $22,23 \mathrm{Oct}$ & 13.7 & 2.2 & & 4.5 & 0.3 \\
\hline & CD1 & $24,25 \mathrm{Oct}$ & 13.9 & 1.6 & & 9.3 & 3.9 \\
\hline & CN1 & $24,25 \mathrm{Oct}$ & 10.8 & 1.0 & & 5.3 & 0.6 \\
\hline
\end{tabular}

Another useful indicator that is used to specify the origin of the emissions is the carbon number with maximum concentration $\left(C_{\max }\right)$. Hydrocarbons and carboxylic acids of high molecular weight $\left(>C_{25}\right)$ are emitted from biogenic sources, while those with lower molecular weight $\left(\leq C_{25}\right)$ are mainly emitted from fossil fuel combustion processes (Alves et al., 2001; Young and Wang, 2002; Gelencsér, 2004).

\subsubsection{Diagnostic ratios of PAHs}

Other indicators that have been used as markers of different source emissions of $\mathrm{OA}$ are the $\mathrm{PAH}$ diagnostic ratios
(DRs) (Dvorská et al., 2011; Katsoyiannis et al., 2011). The DRs calculated in this study are shown in Table 3. The values listed in this table can be found elsewhere (Ravindra et al., 2008; Tobiszewski and Namieśnik, 2012).

\subsection{Chemical mass balance model}

The CMB is a single-sample receptor model that can be stated in terms of the contribution from $p$ independent sources to all chemical species as follows:

$x_{i j}=\sum_{k=1}^{p} g_{i k} f_{k j}+e_{i j}$, 
Table 3. PAH diagnostic ratios for different source categories. The PAH abbreviations are IP: indeno(123cd)pyrene; BgP: benzo(ghi)perylene; BAA: benz(a)anthracene; CRY: chrysene; FLT: fluoranthene; PYR: pyrene; BeP: benzo(e)pyrene; BaP: benzo(a)pyrene.

\begin{tabular}{llll}
\hline Diagnostic ratio & Value & Source & Reference \\
\hline IP / (IP + BgP) & $<0.20$ & Petrogenic & Katsoyiannis et al. (2011) \\
\hline & $>0.20$ & Pyrogenic & Katsoyiannis et al. (2011) \\
& $0.20-0.50$ & Petroleum combustion & Yunker et al. (2002) \\
& $>0.50$ & Coal, grass, and wood combustion & Yunker et al. (2002) \\
\hline BAA / (BAA + CRY) & $<0.20$ & Petrogenic & Katsoyiannis et al. (2011) \\
& $0.20-0.35$ & Coal combustion & Akyüz and Cabuk (2010) \\
& $>0.35$ & Pyrogenic, vehicle emissions & Katsoyiannis et al. (2011) \\
\hline FLT / FLT + PYR) & $<0.40$ & Petrogenic & Katsoyiannis et al. (2011) \\
& $>0.40$ & Pyrogenic & Katsoyiannis et al. (2011) \\
& $0.40-0.50$ & Fuel combustion & Katsoyiannis et al. (2011) \\
& $>0.50$ & Diesel emissions & Ravindra et al. (2008) \\
\hline$(B a P+B e P) / B g P$ & $>0.60$ & Traffic & Katsoyiannis et al. (2011) \\
& $<0.60$ & Non-traffic & Katsoyiannis et al. (2011) \\
\hline
\end{tabular}

where $x_{i j}$ is the measured concentration of species $j$ in sample $i, f_{k j}$ is the concentration of species $j$ in the emissions of source $k, g_{i k}$ is the contribution of source $k$ to sample $i$, and $e_{i j}$ is the model error. This model considers a prior knowledge of the source profiles and that the components of the source emissions do not undergo changes during their transport from the source to the receptor. CMB provides an effective variance-weighted least-squares solution to the overdetermined set of mass balance equations (Eq. 1). CMB takes into account the known uncertainties in the ambient measurements and the source emission data to minimize the chisquare $\left(\chi^{2}\right)$ goodness-of-fit parameter for each sample $i$ :

$\chi^{2}=\sum_{j=1}^{m}\left[\frac{x_{j}-\sum_{k=1}^{p} g_{j k} f_{k}}{\sigma_{x_{j}}^{2}+\sum_{k=1}^{p} \sigma_{g_{j k}} f_{k}}\right]$,

where $\sigma_{x j}$ is the standard deviation of the concentration of species $j, \sigma_{g j k}$ is the standard deviation of the $g_{j k}$, and is $m$ the total number of species. The US EPA-CMB8.2 software has been successfully used to apportion source contributions to ambient $\mathrm{PM}_{2.5}$ (Ke et al., 2007; Stone et al., 2008; Watson et al., 2008; Kleeman et al., 2009; Schneidemesser et al., 2009; Yin et al., 2010; Perrone et al., 2012; Villalobos et al., 2015) and was also used in the current study. More details about CMB can be found elsewhere (e.g., Henry et al., 1984; Watson et al., 2008).

\subsection{Source profiles}

The source profiles used in this work were taken from the most comprehensive studies available. The selection of the source profiles was based on previous source apportionment studies carried out for Mexican urban areas. Firstly, Stone et al. (2008) used CMB with organic molecular markers profiles to estimate contributions from gasoline- and diesel-powered vehicles, vegetative detritus, and biomass burning in Mexico City. Secondly, Martinez et al. (2012) based their factor analysis on trace elements identified primary sources such as industrial sources, motor vehicle exhaust and biomass burning in the MMA. Finally, from these studies, seven primary source profiles were selected.

The source profiles for gasoline- and diesel-powered vehicles were taken from Schauer et al. (2002) and Fraser et al. (2002), respectively. In the MMA, the gasoline vehicle fleet seems to be rather well maintained and of a recent model year, while the diesel vehicle fleet is composed of heavyduty vehicles such as trucks and buses. Therefore, the profiles reported for catalyst-equipped gasoline-powered motor vehicles emissions and heavy-duty trucks from dynamometer tests were used.

From evidence of industrial sources in Mexican urban atmospheres, source profiles for natural gas combustion and fuel oil combustion were taken from Rogge et al. (1993c) and Rogge et al. (1997), respectively.

Finally, source profiles for meat-cooking operations, vegetative detritus, and biomass burning were taken from Schauer et al. (1999), Rogge et al. (1993b), and Schauer et al. (2001a), respectively. Most traditional restaurants activities of the region of study include meat charbroiling operations. For biomass burning, given the existence of softwood and hardwood sources in the region (Zurita, 2009), the softwood pine and hardwood oak profiles were used in this study. These last profiles were used separately because they are highly collinear. Regarding vegetative detritus, a source profile was included based on the contributions determined by Stone et al. (2008) in Mexico City along with the fact that the MMA is surrounded by rural areas with vast green covers. Therefore, 
it is possible to have an impact from transport of biogenic emissions.

For individual organic compound quantification, an uncertainty of $\pm 20 \%$ of the measured concentration was used for all ambient samples and source profiles (Schauer et al., 2000; SRM 1649a, 2007; SRM 1649b, 2009; Fraser et al., 2003; Schantz et al., 2005). A detailed description of the source profiles and settings used to perform the $\mathrm{CMB}$ in this study can be found in Fraser et al. (2003). For the current application, the fitting species for $\mathrm{CMB}$ included 20 organic compounds along with EC and overall OC. The molecular markers included seven $n$-alkanes (C27-C33), four petroleum biomarkers $(17 \mathrm{a}(\mathrm{H}), 21 \mathrm{~b}(\mathrm{H})$-29-norhopane, 17a(H),21b(H)hopane, $22 \mathrm{R}+\mathrm{S} \quad 17 \mathrm{a}(\mathrm{H}), 21 \mathrm{~b}(\mathrm{H})$-30-homohopane, and $22 \mathrm{R}+\mathrm{S} 17 \mathrm{a}(\mathrm{H}), 21 \mathrm{~b}(\mathrm{H})-30$-bishomohopane), five polycyclic aromatic hydrocarbons (benzo[a]anthracene, benzofluoranthenes, benzo[a]pyrene, indeno[123-cd]pyrene and benzo[ghi]perylene), two saturated fatty acids (C16:0 and C18:0), cholesterol, and levoglucosan.

\section{Results and discussion}

\subsection{Resolved organic aerosols}

The results for the chemical characterization of the fine organic aerosol for the MMA are summarized in Table S1. In this and other sections, averaged values for concentrations and other parameters are given \pm 1 standard deviation. Most of the $\mathrm{PM}_{2.5}$ daytime concentrations were $20 \%$ higher than nighttime concentrations. The concentrations of OC and EC were on average $32 \%$ higher during the daytime than the nighttime. In addition, the $\mathrm{OC}$ and $\mathrm{EC}$ accounted together for 28-49 and 46-55\% of the $\mathrm{PM}_{2.5}$ for spring and fall, respectively. In the spring, the daytime carbonaceous fraction was 1.6-1.8 times higher than the corresponding nighttime fraction, whereas during the fall it was 1.1-1.2 times higher. The average OC / EC ratios ranged from 7.4 to 12.6 during this study. Detailed information and analysis of the carbonaceous aerosol for this study can be found in Mancilla et al. (2015).

All samples collected during this study were analyzed for eight organic compound classes except those samples collected in the spring of the 2011 campaign, for which carboxylic acids, wood smoke markers, and nitro-PAH compounds were not included for the chemical analysis. Therefore, the overall contribution of the resolved organic compounds to OC in the spring of 2011 is not directly comparable to that of the last three campaigns. The data for seven of the eight resolved compound classes are shown in Fig. 2. For the last three campaigns, the $n$-alkanoic acids were the most abundant, followed by $n$-alkanes, wood smoke markers, and levoglucosan/alkenoic acids. The PAHs and triterpene hydrocarbons were less abundant. The same tendency was observed in the spring of 2011, except that the $n$-alkanes were the most abundant. The concentrations of nitro-PAH were neglected because their levels were below the detection limit of the method.

The daytime and nighttime concentrations of the resolved organics for spring 2011 accounted for $0.49 \pm 0.52$ and $0.46 \pm 0.41 \%$ of the ambient OC, respectively. These contributions were much lower than the following three campaigns due to the fact that some compounds classes were not included. For spring 2012 and all fall campaigns, the total daytime concentrations of the resolved organics accounted for $7.58 \pm 4.89$ and $2.64 \pm 1.82$ to $4.67 \pm 1.76 \%$, respectively, while the total nighttime concentrations accounted for $11.0 \pm 6.3$ and $3.2 \pm 2.4$ to $8.0 \pm 4.0 \%$, respectively. These observations are consistent with the findings that, typically, around $84 \%$ of the fine OC is either non-extractable or will not elute from the GC column (Schauer and Cass, 2000). In the following sections the organic composition of the fine organic aerosols will be analyzed using several diagnostic ratios to identify the primary emission sources. Then the relative contribution of each primary source to the $\mathrm{PM}_{2.5}$ will be calculated by using the CMB receptor model.

\section{$3.2 n$-Alkanes and hopanes}

The $n$-alkanes have two main sources: petroleum product utilization and natural vegetation waxes. The latter source consists of the longer-chain plant lipids $\left(>C_{20}\right)$ such as $n$ alkanes (Simoneit and Mazurek, 1982). In this study, the $n$ alkanes in the range of $C_{17}-C_{33}$ were detected. For the samples collected for spring 2011 and fall 2011, the average daytime and nighttime concentrations of $n$-alkanes were 1.6 and 2.3 times higher for the fall than the spring, respectively. This is consistent with the high contribution of the $\mathrm{OC}$ to $\mathrm{PM}_{2.5}$ and the lowest OC / EC ratios exhibited during the fall (Mancilla et al., 2015). In addition, the average temperature in the fall was $18.7-22.1^{\circ} \mathrm{C}$ vs. $27.8-29.4^{\circ} \mathrm{C}$ in the spring. Low temperatures typically promote the utilization of petroleum products. In Mexico, the government sets the tariff rates for electric energy consumption with regard to the temperature; during the cold seasons the government removes the subsidy on domestic electric energy due to the demand for fossil fuels in those seasons, and the sampling years of this study were not the exception (SENER, 2013). The average CPI values of $n$-alkanes in the spring were $1.5 \pm 0.3$ (range: $1.1-1.9$ ) in the daytime and $1.7 \pm 0.5$ (range: $1.1-2.6$ ) in the nighttime, while the CPI values in the fall were $1.0 \pm 0.3$ (range: $0.7-1.2$ ) in the daytime and $0.9 \pm 0.1$ (range: $0.7-$ $1.0)$ in the nighttime. The CPI values in the spring suggest the mixed contribution of anthropogenic and biogenic emission sources, whereas those values in the fall indicated a dominance of anthropogenic emissions. In addition, the contribution of anthropogenic emission sources is confirmed by the presence of petroleum biomarkers (hopanes: range of 0.06 to $2.36 \mathrm{ng} \mathrm{m}^{-3}$ ) and $n$-alkanes $\leq C_{25}$ (Fig. 3). For the fall, the average daytime and nighttime concentrations of hopanes 

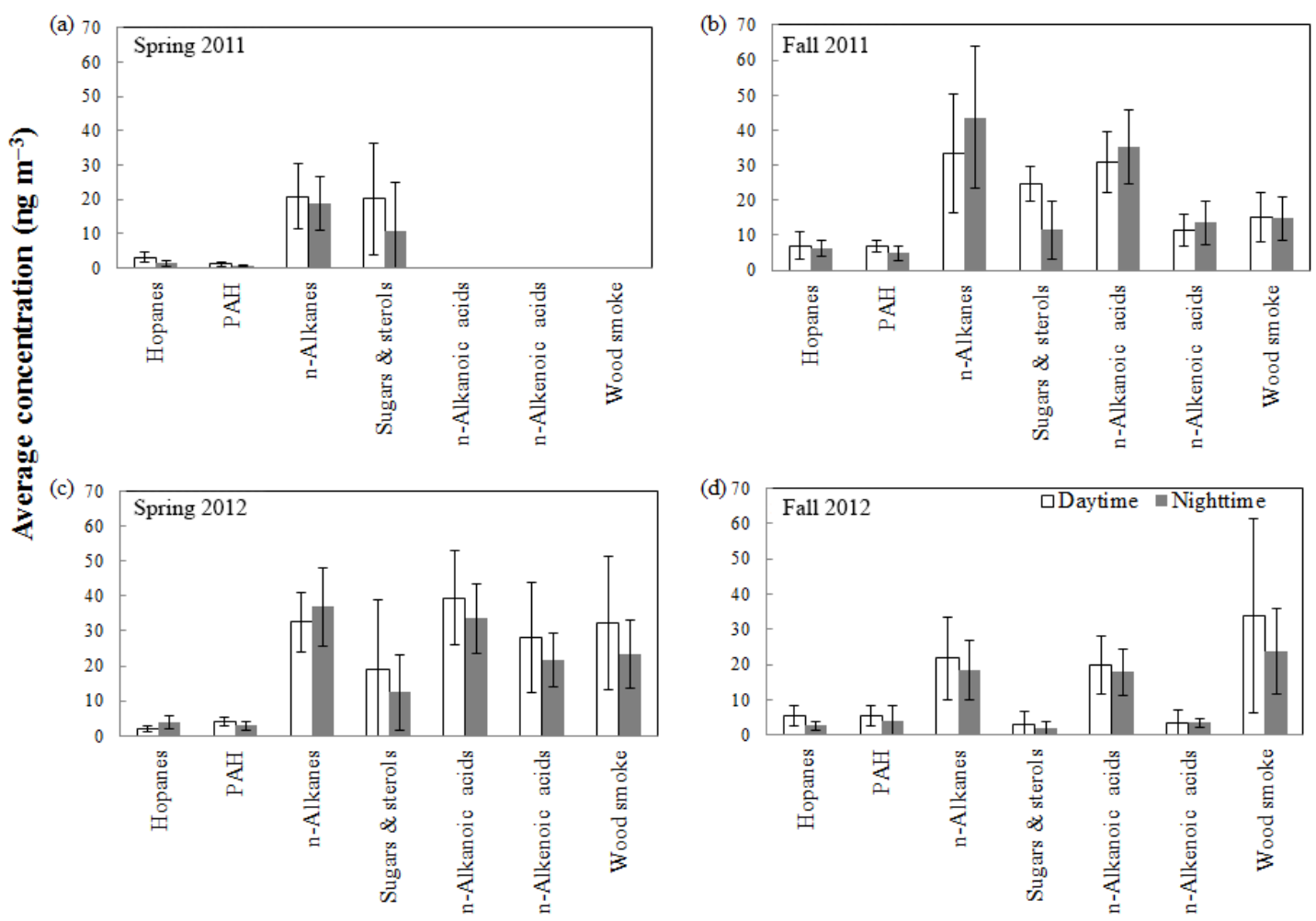

Figure 2. Concentrations of the resolved organic compound classes in the MMA. For (a) the $n$-alkanoic and alkenoic acids and wood smoke tracer were not included in the chemical analysis. For (b), (c) and (d) the $n$-alkanoic acids are divided by a factor of 10 .

were 2.3 and 4.2 times higher than in the spring, respectively. Similarly, the presence of biogenic emissions due to $C_{\max }$ was found at $C_{27}, C_{29}$, or $C_{31}$ (Fig. 3). This carbon number dominance and trace levels of hopanes are characteristics of plant wax emissions and urban traffic emissions, respectively (Standley and Simoneit, 1987; Cass, 1998; Simoneit et al., 2004).

For spring 2012 and fall 2012, the behavior of $n$-alkanes was the opposite of 2011. The average daytime and nighttime concentrations of $n$-alkanes were 1.5 and 2.0 times higher in the spring than in the fall, respectively. The EC levels remained similar to those of 2011 , but the OC levels were higher during fall 2012, increasing the OC / EC ratios. Some of these ratios exhibited high peaks suggesting a contribution from primary emission sources with elevated OC / EC ratios like biomass burning (Mancilla et al., 2015). The average temperature in the fall was $23.5-26.4^{\circ} \mathrm{C}$ vs. $28.0-30.7^{\circ} \mathrm{C}$ in the spring. The average fall temperatures were not consistent with the average of 2011. In the fall of 2012, the warmer temperatures might have promoted less utilization of some fuels compared to 2011 in which lower temperatures could have promoted their utilization, increasing the $n$-alkanes' concentrations in fall 2011. The average CPI values of $n$-alkanes in spring 2012 were $0.9 \pm 0.1$ (range: $0.8-1.1$ ) in the daytime and $1.2 \pm 0.1$ (range: $1.2-1.3$ ) in the nighttime, while the CPI values in fall 2012 were $1.3 \pm 0.1$ (range: $1.0-1.4$ ) in the daytime and $1.5 \pm 0.2$ (range: 1.3-1.6) in the nighttime. From these CPI values, it appears that biogenic emissions are relevant in all sampling periods. For spring 2012 daytime, the emissions appear to be heavily dominated by anthropogenic emissions due to the low CPI value exhibited. The presence of petroleum biomarkers supports the relative contribution of anthropogenic emissions. However, in 2012 the hopane levels were $\sim 35 \%$ lower at daytime and $\sim 43 \%$ lower at nighttime than those in the previous year. The low hopane levels (range of 0.10 to $1.49 \mathrm{ng} \mathrm{m}^{-3}$ ) highlight the possible presence of biogenic emissions (Fig. 2).

\subsection{PAHs}

Twelve PAH compounds - fluoranthene (FLT), acephenanthrylene (ACE), pyrene (PYR), benzo(a)anthracene (BAA), chrysene (CRY), benzo(k)fluoranthene + benzo(b)fluoranthene (BFA), benzo(a)pyrene + benzo(e)pyrene $(\mathrm{BaP}+\mathrm{BeP})$, perylene (PER), indeno(123cd)pyrene (IP), benzo(ghi)perylene $(\mathrm{BgP})$, dibenz(ah)anthracene (DaA), and coronene (Cor) were identified in the MMA fine samples. For both sampling years, the average daytime and nighttime concentrations of PAHs were 1.4-5.9 and 1.4-2.4 times higher in the fall than in the spring, respectively. This is consistent with the high contribution of the $\mathrm{OC}$ to the $\mathrm{PM}_{2.5}$ during the falls. 

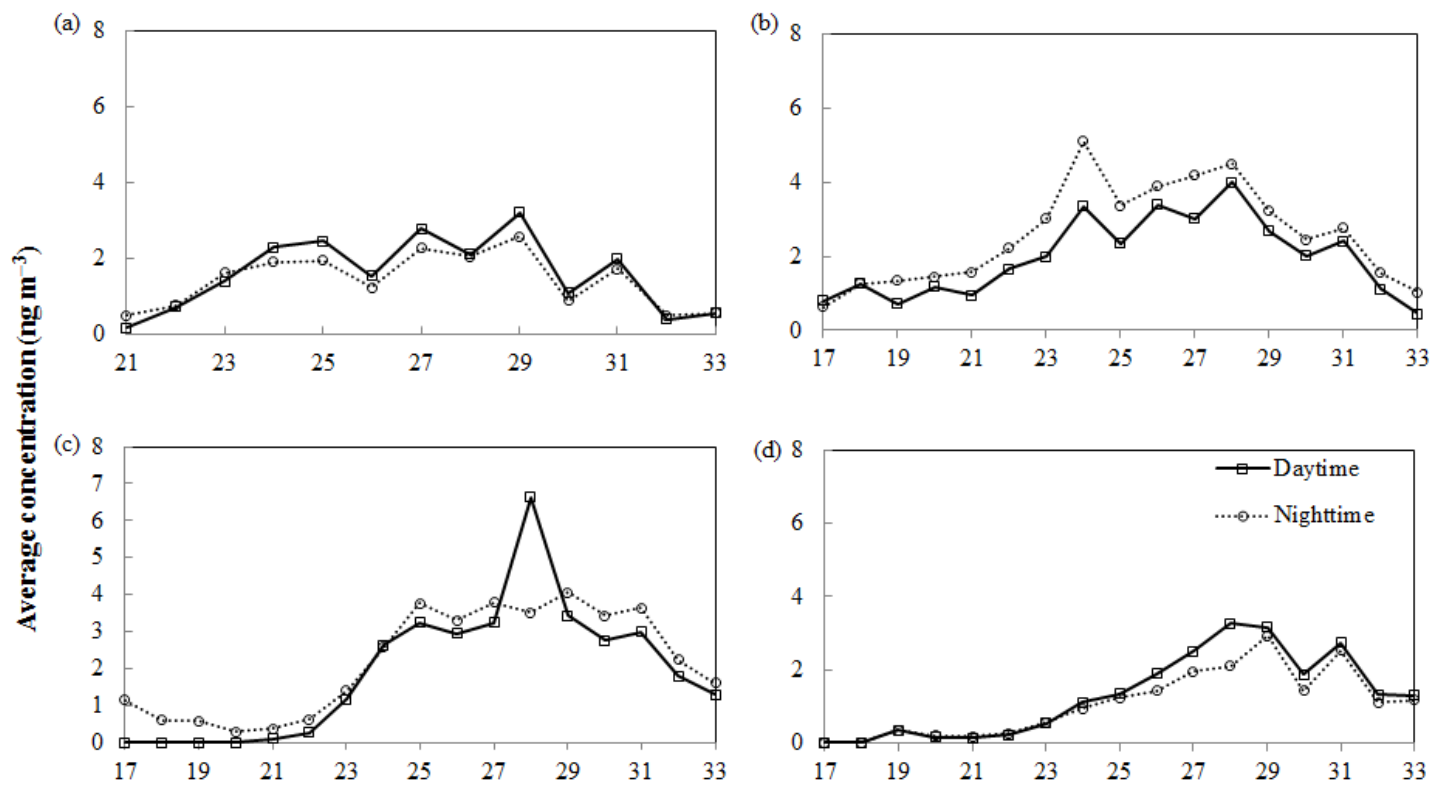

Carbon number

Figure 3. Carbon number distribution of $n$-alkanes in the Monterrey metropolitan area (MMA) for (a) spring 2011, (b) fall 2011, (c) spring 2012, and (d) fall 2012. The black line represents the daytime concentrations, while the dotted line represents the nighttime concentrations.

Independent of the season, the daytime concentrations were 1.3-1.6 times higher than nighttime concentrations. These seasonal differences are consistent with the results of Guo et al. (2003) and $\mathrm{Li}$ et al. (2006), where PAH levels were 2-4 and 14.4 times higher in the cold seasons than in the warm seasons, respectively.

As illustrated in Fig. 4, the high-molecular-weight (HMW) PAHs were the most abundant for the MMA. The presence of HMW PAHs such as $\mathrm{BaP}+\mathrm{BeP}, \mathrm{IP}$, and $\mathrm{BgP}$ is an indication of gasoline-powered vehicle emissions (Katsoyiannis et al., 2011; Tobiszewski and Namieśnik, 2012). In addition, a possible contribution of diesel-powered vehicles is indicated by the low concentrations of the low-molecular-weight (LMW) PAHs such as FLT, PYR, and CRY. To identify the emission sources of PAH, diagnostic ratios were calculated (Table 4). These ratios should be used with caution because PAHs are emitted from a variety of emission sources, particularly combustion sources, and their profiles can be modified due to their reactivity (Tsapakis et al., 2002). From these ratios, the source could be determined (e.g., pyrogenic and petrogenic sources). Then, these qualitative conclusions will be considered for the source apportionment to estimate the relative contribution of primary emission sources. The average ratios of IP / (IP + BgP) indicate that ambient PAHs in the MMA originated from gasoline and diesel combustion, whereas the ratios of BAA / (BAA + CRY) show the presence of petrogenic sources as well as vehicle emissions. To complement these results, the ratios of $(\mathrm{BaP}+\mathrm{BeP}) / \mathrm{BgP}$ identified a marked contribution of non-traffic sources for the spring of
2011, traffic sources for fall 2011 and spring 2012, and mixed sources for fall 2012. The presence of gas-phase PAHs was not evaluated and thus no information on gas-particle partitioning of these semivolatile species is available. Thus, only diagnostic ratios for HMW PAHs were calculated for this study because those PAHs exhibit low volatility (Kavouras et al., 1999).

In this study, the average total concentrations of the quantified PAHs (TPAHs) were $2.42 \pm 2.45 \mathrm{ng} \mathrm{m}^{-3}$ (range: 0.65 8.31 and $4.11 \pm 2.62 \mathrm{ng} \mathrm{m}^{-3}$ (range: $1.42-11.97 \mathrm{ng} \mathrm{m}^{-3}$ ) during 2011 and 2012, respectively, whilst those quantified by González-Santiago (2009) at two different sites in the MMA were $1.30 \pm 1.64 \mathrm{ng} \mathrm{m}^{-3}$ (range: $0.05-6.93$ ) and $1.70 \pm 1.88 \mathrm{ng} \mathrm{m}^{-3}$ (range: $0.07-9.14 \mathrm{ng} \mathrm{m}^{-3}$ ). The lowest concentrations were obtained during the spring because its average temperature was statistically higher than during the fall seasons $(p<0.05)$. The volatility of PAH increases with temperature; as a result low concentrations are obtained in comparison with fall and winter seasons. For this study the concentrations of PAH were lower during the spring than concentrations during fall; this pattern was exhibited during the two sampling years. González-Santiago (2009) identified only 6 PAHs, while in this study were 12 identified. In the current study, the total concentrations calculated for the six common PAHs were from 3 to 8 times higher than those estimated by González-Santiago (2009). Similar concentrations (between 0.04 and $1.78 \mathrm{ng} \mathrm{m}^{-3}$ ) were also reported for six individual PAHs in urban samples collected in Mexico City (Stone et al., 2008). Of the same PAHs identified among 
Table 4. Average diagnostic ratios of PAHs in MMA. D represents daytime and $\mathrm{N}$ represents nighttime.

\begin{tabular}{llrrrr}
\hline Season & Period & IP / (IP + BgP) & BAA / (BAA + CRY) & FLT / (FLT + PYR $)$ & $(\mathrm{BaP}+\mathrm{BeP}) / \mathrm{BgP}$ \\
\hline Spring 2011 & $\mathrm{D}$ & $0.41 \pm 0.05$ & $0.34 \pm 0.28$ & $0.50 \pm 0.03$ & $0.19 \pm 0.24$ \\
& $\mathrm{~N}$ & $0.46 \pm 0.02$ & $0.62 \pm 0.30$ & $0.49 \pm 0.10$ & $0.07 \pm 0.06$ \\
\hline Fall 2011 & $\mathrm{D}$ & $0.35 \pm 0.10$ & $0.50 \pm 0.03$ & $0.55 \pm 0.12$ & $2.67 \pm 0.75$ \\
& $\mathrm{~N}$ & $0.51 \pm 0.26$ & $0.17 \pm 0.29$ & $0.66 \pm 0.25$ & $4.63 \pm 4.49$ \\
\hline Spring 2012 & $\mathrm{D}$ & $0.33 \pm 0.13$ & $0.01 \pm 0.003$ & $0.72 \pm 0.20$ & $4.48 \pm 2.19$ \\
& $\mathrm{~N}$ & $0.47 \pm 0.34$ & $0.06 \pm 0.12$ & $0.89 \pm 0.02$ & $10.40 \pm 2.45$ \\
\hline Fall 2012 & $\mathrm{D}$ & $0.34 \pm 0.04$ & $0.35 \pm 0.07$ & $0.60 \pm 0.06$ & $0.55 \pm 0.08$ \\
& $\mathrm{~N}$ & $0.36 \pm 0.02$ & $0.40 \pm 0.09$ & $0.68 \pm 0.05$ & $0.52 \pm 0.13$ \\
\hline
\end{tabular}

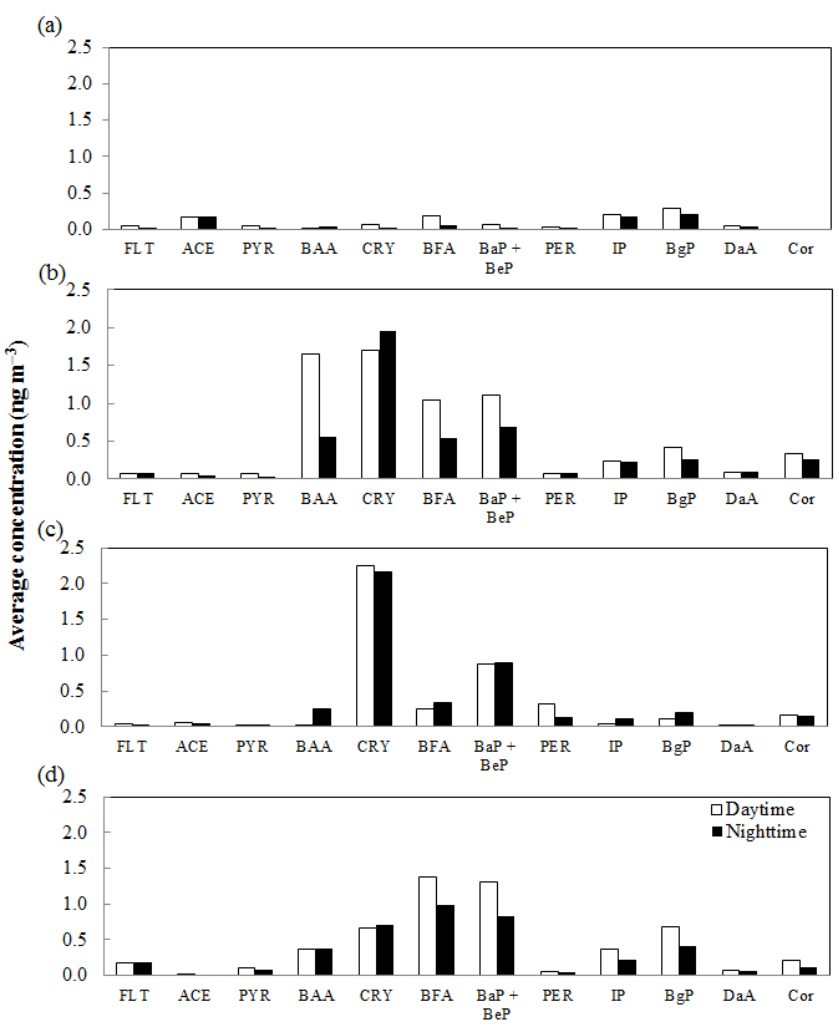

Figure 4. Mass concentration distribution of PAHs in the Monterrey metropolitan area (MMA) for (a) spring 2011, (b) fall 2011, (c) spring 2012, and (d) fall 2012. Coronene was included in all monitoring campaigns except in spring 2011.

these studies, their levels were in the same concentration range. However, the TPAH levels in the MMA compared to those calculated by Marr et al. (2006) (20-100 $\mathrm{ng} \mathrm{m}^{-3}$ ) in Mexico City were found at appreciably lower concentrations. In addition, Marr et al. (2006) suggest that vehicles are the major source of PAHs. They demonstrated that PAHs and carbon monoxide (CO) concentrations are well correlated in Mexico City and, given that $99 \%$ of CO emissions are emitted by motor vehicles, this source is a major contribution of
PAH emissions. For the current study, daytime correlations $(r)$ of $+0.76(p>0.05)$ were found between TPAH and CO, reinforcing the conclusion that motor vehicles are one major source of PAH emissions for the MMA. The concentrations of CO during this study were obtained from the SIMA network.

The TPAH concentrations were compared with the EC and OC levels. TPAH concentrations measured in the MMA exhibited fair daytime correlations with EC $(r=$ $+0.79 ; p>0.05)$, but low correlations with OC $(r=+0.57$; $p>0.05)$. According to Marr et al. (2004), the strong correlation between TPAH and EC indicated the relative contribution of diesel-powered vehicle exhaust, while weak correlations may be due to the low concentrations of EC determined during this study (Mancilla et al., 2015). Furthermore, the weak correlation between TPAH and EC suggests the presence of emission sources with an elevated OC / EC.

\section{4 n-Alkanoic acids}

The carboxylic acids or $n$-alkanoic acids are mainly derived from biogenic emissions (Rogge et al., 1993b). However, these acids have also been identified in several primary sources such as cooking operations (Rogge et al., 1991; Schauer et al., 2001b) and fossil fuel combustion (Schauer et al., 2002). The $n$-alkanoic acids from $C_{10}$ to $C_{32}$ were quantified only for the three last monitoring campaigns. The $n$-alkanoic acids were the most abundant, accounting for $69 \pm 16 \%$ at daytime and $78 \pm 11 \%$ of the total resolved organics at nighttime for both spring and fall. The daytime and nighttime concentration levels were 2 times higher in the spring than in the fall. As can be seen in Fig. 5 , the $n$-alkanoic acids measured in the MMA were dominated by hexadecanoic acid (palmitic acid) and octadecanoic acid (stearic acid). This dominance is consistent with measurements in other locations (Fraser et al., 2002; Simoneit 2004; Li et al., 2006).

The average CPI values of $n$-alkanoic acids in the fall of 2011 were $4.3 \pm 1.0$ (range: $3.3-5.3$ ) during the day and $5.0 \pm 0.4$ (range: $4.6-5.4$ ) at night. For the 2012 year the CPI 

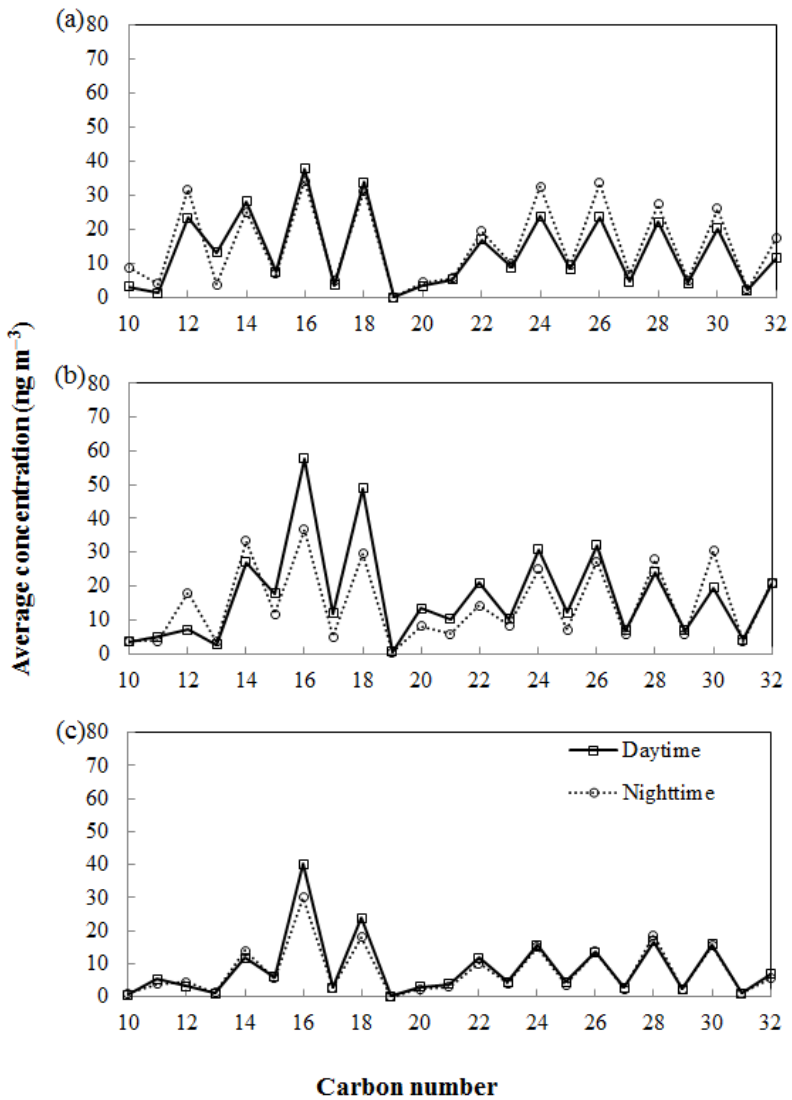

Figure 5. Carbon number distribution of $n$-alkanoic acids in the Monterrey metropolitan area (MMA) for (a) fall 2001, (b) spring 2012, and (c) fall 2012. The black line represents the daytime concentrations while the dot line represents the nighttime concentrations.

values in the spring were $3.6 \pm 0.6$ (range: $2.9-4.5$ ) during the day and $4.7 \pm 0.8$ (range: $3.9-5.8$ ) at night, while the CPI values in the fall were $4.7 \pm 0.3$ (range: $4.3-5.1$ ) during the day and $5.3 \pm 1.1$ (range: $4.0-6.8$ ) at night. These elevated CPI values indicated the significant influence of biogenic sources such as microbial and plant wax sources. The $n$-alkanoic acids $<C_{20}$ are derived in part from microbial sources, while those $>C_{20}$ are from vascular plant waxes (Guo et al., 2003; Yue and Fraser, 2004; Simoneit et al., 2004). Figure 5 clearly shows the influence of long-chain $\left(>C_{20}\right.$ ) plant wax particles for the MMA. The CPI values in this study were consistent with those obtained by Wang and Kawamura (2005) (CPI: 5.3-10) and Yue and Fraser (2004) (CPI: 3.2-11.2). Regardless of the elevated CPI values obtained for the MMA, the values were not as high as those reported by the other mentioned studies due to a scarcity of green vegetation covers in the MMA.

The alkenoic acids only included cis-9-octadecenoic acid (oleic acid) and trans-9-octadecenoic acid (elaidic acid). The concentrations of $c i s$-9-octadecenoic acid ranged from 0.96 to $15.38 \mathrm{ng} \mathrm{m}^{-3}$, while the concentrations of trans-9- octadecenoic acid ranged from 2.11 to $13.35 \mathrm{ng} \mathrm{m}^{-3}$. The ratio of octadecanoic acid to cis-9-octadecenoic acid has been used as an indicator of the atmospheric chemical processing (aging) of aerosols, since the unsaturated acids are susceptible to atmospheric oxidation (Brown et al., 2002; Yue and Fraser, 2004). In this study, the average ratios were 5.0 (range: 1.5-9.4) during the day and 3.8 (range: 2.5-4.9) at night for the spring, vs. 20.3 (range: 4.7-38.6) during the day and 21.0 (range: 10.5-29.1) at night for the fall. The transport of aerosols from local and rural sources can lead to the loss of cis-9-octadecenoic acid producing high ratios of octadecanoic acid to cis-9-octadecenoic acid. Similarly, air mass stagnation may lead to high oxidant concentrations in an urban atmosphere producing high ratios (Brown et al., 2002; Yue and Fraser, 2004). Therefore, these ratios suggest that the ambient organic aerosols for the MMA were aged and might be produced from transport and atmospheric oxidation. Air circulation patterns (HYSPLIT backward trajectories) during these monitoring campaigns suggested longrange transport from the northeast and southeast (Mancilla et al., 2015). As expected, the lowest and highest octadecanoic acid to cis-9-octadecenoic acid ratios obtained for the MMA were consistent with the highest $\mathrm{OC} / \mathrm{EC}$ ratios estimated for the MMA for the same campaign; high OC / EC ratios identified transport and stagnation scenarios for the spring and fall, respectively (Mancilla et al., 2015). In addition, these results are in line with those reported by Brown et al. (2002) and Yue and Fraser (2004), who obtained ratios of 5-11 and $1.0-21.5$, respectively.

In addition, a minor biogenic contribution can be identified by the presence of terpenoic acids such as cis-pinonic acid and pinic acid. These acids are known to be a secondary, particle-phase products of pinene, which is emitted from plants, particularly conifers (Plewka et al., 2006; Sheesley et al., 2004). Both pinonic and pinic acid exhibited higher concentrations in the spring than in the fall (Table S1 in the Supplement), indicating biogenic emissions from softwood sources.

\subsection{Meat-cooking and biomass burning tracers}

The major tracers for meat-cooking particles are the steroids, while those for biomass burning are the anhydrosaccharides and methoxyphenols. All of these organic tracers were intermittent in only $80 \%$ of the total OA samples/composites collected during this study.

There was no clear trend between spring and fall samples during the two sampling years for steroids (Table S1). However, the evidence of cooking operations' impact on the MMA was confirmed by the presence of cholesterol and stigmasterol along with hexadecanoic acid, octadecanoic acid, and oleic acid. Although cholesterol is considered a good marker for meat cooking, studies have reported unexpectedly high levels of cholesterol from non-cooking-related sources 
such as soil and prescribed burns (Sheesley et al., 2004; Lee et al., 2005; Robinson et al., 2006a).

Anhydrosaccharides are tracers from burning cellulose and hemicelluloses, whereas the methoxyphenols are a tracer from burning of lignin (Giri et al., 2013). Levoglucosan, a combustion and pyrolysis product of cellulose, is the main biomarker used to track biomass burning emissions (Schauer et al., 2001a). Levoglucosan was not detected in all collected samples. The levoglucosan found in the samples indicates that biomass burning is impacting the MMA to some extent (Table S1). The levoglucosan concentrations varied by sampling dates, ranging from non-detectable levels to $54 \mathrm{ng} \mathrm{m}^{-3}$ for spring. In contrast, levoglucosan was detected in all fall samples, ranging from 0.14 to $28 \mathrm{ng} \mathrm{m}^{-3}$. The intermittent peaks of levoglucosan concentrations during the springtime can be explained by the fact that northeastern Mexico's atmosphere is highly influenced by forest wildfires and prescribed agricultural burnings during the spring (Mendoza et al., 2005); this is in line with the idea that high OC / EC ratios obtained, in a parallel study, were influenced in part by regional transport emissions (Mancilla et al., 2015). In the case of the fall seasons, the levoglucosan levels can be associated with local biomass burning due to mild temperatures encountered during these seasons; a local contribution can be associated with high OC / EC ratios and stagnation conditions determined for this period (Mancilla et al., 2015). The high OC / EC rations during spring may have a contribution from primary sources with elevated OC / EC ratios. The low and variable levoglucosan concentrations in this study indicate that wood/vegetation smoke episodes were occasional at the urban site. Average levoglucosan concentrations of 112.9 and $151.3 \mathrm{ng} \mathrm{m}^{-3}$ were reported at urban and peripheral sites for Mexico City, respectively (Stone et al., 2008). Based on an average concentration of levoglucosan, Mexico City exhibited from 5 to 7 times higher levels than the MMA. These results are consistent with the concentrations of OC and EC obtained in Mexico City; the EC concentrations were up to 2 times higher than those observed in the MMA, whereas the OC concentrations were from 2 to 6 times higher. A study conducted in Houston, TX, during August-September reported elevated concentrations of levoglucosan: up to $234 \mathrm{ng} \mathrm{m}^{-3}$ (Yue and Fraser, 2004). Similarly, a study conducted for 14 cities in China during summer and winter also reported elevated levoglucosan concentrations of $259 \mathrm{ng} \mathrm{m}^{-3}$ (Wang et al., 2006). However, in those studies the vegetation around the sampling sites included a vast number of parks and woody shrubs, suggesting a major biomass burning contribution contrary to the MMA. Apart from those studies, Zheng et al. (2002) reported elevated levoglucosan concentrations of $166-307 \mathrm{ng} \mathrm{m}^{-3}$ for urban areas of similar surroundings to the MMA. In this case, it is also possible that the levoglucosan emissions reported come from industries that have implemented biomass burning processes for energy generation. As can be seen from the previous comparison, the contribution of biomass burning is minor for the
MMA in comparison with other urban locations. In addition, biomass burning contributions are inconsistent with those reported in similar locations to the MMA.

Resin acids such as dehydroabietic acid, pimaric acid, and isopimaric acid (Table S1) are secondary tracers from biomass burning (Schauer et al., 2001a). Dehydroabietic acid was the most abundant resin acid, ranging from 1.94 to 4.39 and 1.95 to $3.69 \mathrm{ng} \mathrm{m}^{-3}$ for spring and fall, respectively. Then, pimaric acid ranged from not detectable levels to 0.09 and from 0.15 to $0.35 \mathrm{ng} \mathrm{m}^{-3}$ for spring and fall, respectively. Finally, isopimaric acid ranged from not detectable levels to $0.03 \mathrm{ng} \mathrm{m}^{-3}$ and from 0.06 to $0.12 \mathrm{ng} \mathrm{m}^{-3}$ for spring and fall, respectively. The results for resin acids are in line with those obtained for levoglucosan. These results support the low impact from biomass burning emissions in the MMA, especially from softwood burning (e.g., conifer wood) during the spring and fall campaigns. In addition, the higher concentrations of resin acids in fall than in spring are associated with photochemical activity due to stagnation events in fall.

\subsection{Source apportionment}

CMB was applied using the quantification of individual organic compounds found in the collected $\mathrm{PM}_{2.5}$ samples. The relative contributions for gasoline-powered vehicles, dieselpowered vehicles, natural gas combustion, fuel oil combustion, meat-cooking operations, vegetative detritus, and biomass burning were estimated. From the source categories selected, the ones corresponding to natural gas and fuel oil combustion were not determined as significant for some ambient samples. These two sources were determined to have contributions that were not statistically different from zero or were slightly negative and thus were excluded from the model. Model performance was determined by $r^{2}$ values ranging between 0.58 and 0.85 and chi-squared $\left(\chi^{2}\right)$ values between 2.97 and 8.85. Similar values for $r^{2}$ and $\chi^{2}$ have been obtained in Fraser et al. (2003) and Schneidemesser et al. (2009). The latter study used composites to perform the CMB. Another performance metric calculated by EPACMB8.2 is the percent mass explained. Theoretically, values ranging from 80 to $120 \%$ are acceptable. This ideally can occur when ambient data are not impacted heavily by SOA because CMB is only able to account accurately for primary sources. In spite of this limitation, CMB results with low percent mass explained values have been reported by some studies. In these cases, the high levels of unexplained mass have been associated with secondary production (Fraser et al., 2003; Zheng et al., 2005). For the 43 ambient samples fed to CMB in this study, 18 samples exhibited low percent mass explained values (ranging from 20 to $77 \%$ ), whereas 14 samples had values around $100 \%$. These results are in line with the relatively high and low OC / EC ratios obtained for spring and fall, respectively (Mancilla et al., 2015). Finally, 11 samples were discarded due to poor performance parameters calculated. These samples were not exclusively from 
a particular monitoring campaign; there were samples from both springs and falls. A detailed description of the CMB performance and relative contributions for each sample can be found in Table S2.

The average contributions of primary sources are shown in Table 5. The vehicle exhaust and meat-cooking operation emissions were the highest for all monitoring campaigns. When examining the seasonal variation, the gasoline- and diesel-powered vehicles in falls were up to 5 times higher than in springs, when cold weather increases the demand for petroleum products due to low temperatures. The opposite occurred for meat-cooking operations, their spring emissions were 3 times higher than in fall seasons. The natural gas combustion, vegetative detritus, and biomass burning emissions were very low and more constant throughout the springs and falls. With regard to the daytime and nighttime variations, the vehicle exhaust were much higher during daytime when traffic is heavier. For the meat-cooking operations, the emissions were somewhat higher during nighttime during spring and more constant between daytime and nighttime during fall. For the rest of the sources, the daytime and nighttime emissions were relatively constant. No similar studies have been conducted in the MMA; this is the first source apportionment study based on molecular organic markers for this region. However, these results are similar to those obtained for the MMA using a factor analysis based on trace elements (Martinez et al., 2012) and those for Mexico City based on molecular organic markers (Stone et al., 2008).

The average contribution of each emission category to the identified $\mathrm{PM}_{2.5}$ mass is shown in Fig. 6. The unidentified mass was on average $35 \pm 24 \%$ of the measured $\mathrm{PM}_{2.5}$ concentrations. This value is 1.5 times greater than the $\sim 23 \%$ of secondary organic aerosol contribution to the total $\mathrm{PM}_{2.5}$ mass concentration ( $\mathrm{SOC} / \mathrm{PM}_{2.5}$ ) estimated in Mancilla et al. (2015) for the MMA. The average secondary contribution used for this comparison was based on the minimum OC / EC ratios observed and reported in Mancilla et al. (2015). These ratios may take into account primary sources with elevated values of OC / EC ratios such as biomass burning and kitchen operations as well as fossil fuel combustion sources. The mass not identified by CMB may include secondary organic and inorganic aerosol and trace elements. Thus, the levels of unidentified mass resolved by $\mathrm{CMB}$ are reasonable given that the secondary aerosol estimated in Mancilla et al. (2015) was in fact only SOA. Therefore, the $12 \%$ of difference between 35 and $23 \%$ might be attributed to secondary inorganic aerosol and other chemical species. As indicated in Fig. 6, the emissions from motor vehicle exhausts (gasoline and diesel) are the most important, accounting for the $64 \%$ of the identified $\mathrm{PM}_{2.5}$ emissions, followed by meat-cooking operations (31\%) and industries $(2.8 \%)$. Vegetative detritus and biomass burning were the least emitted, with only $2.2 \%$ of the identified $\mathrm{PM}_{2.5}$ emissions. The relatively high contribution of the meat-cooking operations was expected given the high traditional restau- (a)

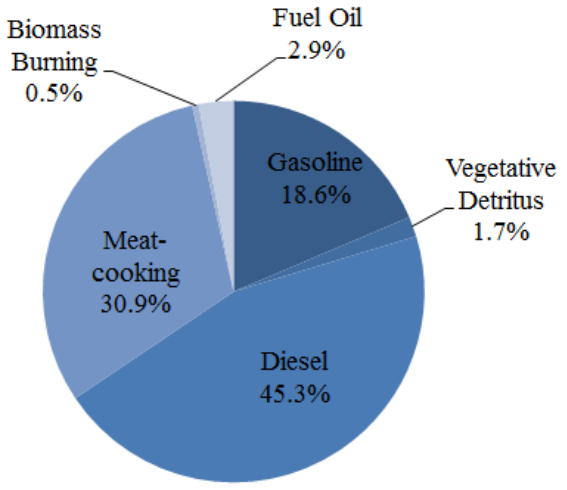

(b)

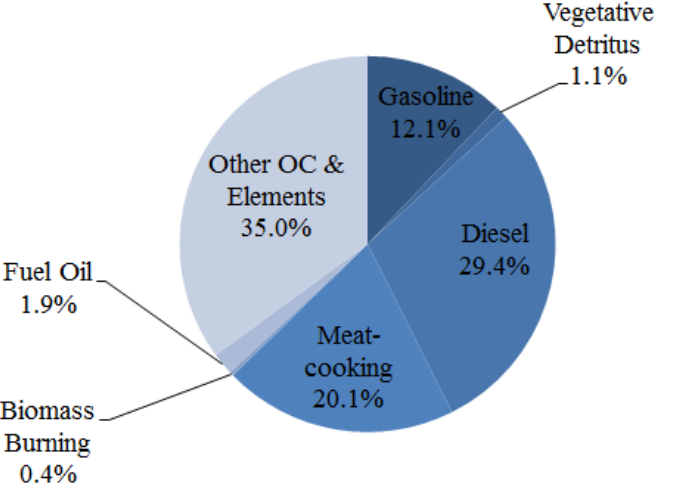

Figure 6. $\mathrm{CMB}$ contributions to the (a) average identified ambient $\mathrm{PM}_{2.5}$ in the MMA and to the $(\mathbf{b})$ overall $\mathrm{PM}_{2.5}$ including the unidentified mass of the measured $\mathrm{PM}_{2.5}$ concentrations.

rant activity in the MMA, which contributes $16 \%$ of the local gross domestic product. With regard to biomass burning, several studies have demonstrated that Mexico City has a large contribution of biomass burning emissions due to forest fires (Moffet et al., 2008; Stone et al., 2008; Yokelson et al., 2007). However, the MMA can be affected by other types of biomass burning (e.g., shrub and grassland fires, agricultural waste and garbage burning) that may be ignored. Therefore, the contribution of biomass burning in the MMA might be higher because the source profile used for the CMB was only for wood combustion instead of using a source profile for other types of biomass burning (Simoneit et al., 2005). In addition, it is important to point out the potential of industrial sources that appeared in previous studies conducted in the MMA and the rest of the country. The MMA is the third largest urban center of the country, with approximately 9700 industries (SIEM, 2016). In the MMA the main emissions from industrial sources come from the combustion of natural gas; low emissions come from the use of fuel oil. In this study the natural gas profile did not fit well and was discarded from the CMB, but the fuel oil profile did. The combustion of natural gas emits a low quantity of particles; therefore, its contribution to the airborne particles is not significant. 
Table 5. Contributions and uncertainty of primary sources to seasonal average ambient $\mathrm{PM}_{2.5}$ for daytime and nighttime in the MMA (in $\left.\mu \mathrm{g} \mathrm{m}^{-3}\right)$.

\begin{tabular}{|c|c|c|c|c|c|c|c|c|}
\hline \multirow[t]{2}{*}{ Source category } & \multicolumn{2}{|c|}{ Spring 2011} & \multicolumn{2}{|c|}{ Fall 2011} & \multicolumn{2}{|c|}{ Spring 2012} & \multicolumn{2}{|c|}{ Fall 2012} \\
\hline & Daytime & Nighttime & Daytime & Nighttime & Daytime & Nighttime & Daytime & Nighttime \\
\hline Gasoline-powered vehicles & $2.37 \pm 0.56$ & $2.46 \pm 0.46$ & $3.70 \pm 0.78$ & $2.24 \pm 0.51$ & $1.43 \pm 0.41$ & . & $7.51 \pm 1.27$ & $3.19 \pm 0.54$ \\
\hline Diesel-powered vehicles & $7.34 \pm 0.86$ & $3.81 \pm 0.53$ & $13.67 \pm 1.59$ & $13.10 \pm 1.55$ & $2.93 \pm 0.41$ & $*$ & $13.85 \pm 1.58$ & $5.15 \pm 0.62$ \\
\hline Vegetative detritus & $0.22 \pm 0.04$ & $0.22 \pm 0.04$ & $0.13 \pm 0.03$ & $0.27 \pm 0.05$ & $0.40 \pm 0.06$ & $*$ & $0.42 \pm 0.07$ & $0.31 \pm 0.05$ \\
\hline Meat-cooking operations & $8.24 \pm 1.54$ & $11.13 \pm 1.85$ & $3.26 \pm 0.71$ & $3.86 \pm 0.71$ & $9.74 \pm 1.20$ & * & $3.22 \pm 0.53$ & $3.37 \pm 0.47$ \\
\hline Natural gas combustion & $0.01 \pm 0.01$ & N.I. & $0.05 \pm 0.03$ & $0.03 \pm 0.01$ & $0.01 \pm 0.01$ & * & $0.10 \pm 0.02$ & $0.04 \pm 0.01$ \\
\hline Biomass burning & $0.20 \pm 0.05$ & $0.17 \pm 0.05$ & $0.17 \pm 0.05$ & $0.07 \pm 0.02$ & $0.16 \pm 0.04$ & * & $0.01 \pm 0.01$ & $0.01 \pm 0.01$ \\
\hline Fuel oil combustion & N.I. & N.I. & $4.18 \pm 3.55$ & $3.60 \pm 1.20$ & N.I. & * & N.I. & $0.22 \pm 0.48$ \\
\hline
\end{tabular}

N.I. means not important. ${ }^{*}$ Samples were discarded due to poor CMB performance.

\section{Conclusions}

Spring and fall sampling campaigns were performed in 2011 and 2012 at one representative site to conduct a chemical characterization of the fine $\mathrm{OC}$ in $\mathrm{PM}_{2.5}$ in the MMA. The identified organic compound classes represented a low fraction of the ambient OC: $0.5 \%$ for spring 2011 and 2.6 to $11 \%$ for the last three campaigns. The average CPI values derived from the $n$-alkanes (0.9-1.7) and $n$-alkanoic acids (2.9-6.8) demonstrated that anthropogenic emission sources (e.g., fossil fuel combustion) were dominant, while biogenic (e.g., plant waxes, microbial origin) emission sources contribute at least sometimes to the fine OA in the MMA.

The PAH diagnostic ratios indicate that gasoline- and diesel-powered vehicles are the main emission sources of this class of organic compounds in $\mathrm{PM}_{2.5}$. However, other pyrogenic sources such as coal, grass, and wood combustion were also identified as contributors to the fine OA. The quantified levels of cholesterol and levoglucosan confirm the high and low contribution of cooking operations and biomass burning, respectively. Low levoglucosan concentrations suggest low episodic or transport effects of emissions of biomass burning on $\mathrm{PM}_{2.5}$ in the MMA.

In a parallel study, significant SOA formation was found in the MMA. The chemical speciation of the OC confirmed the aging of primary emissions and the SOA from biogenic volatile organic compounds. On the one hand, the identified octadecanoic acid and cis-9-octadecenoic acid along with other secondary organic markers point out the SOA formation in the MMA atmosphere. The average ratios of octadecanoic acid to $c i s$-9-octadecenoic acid (3.8-21) indicate aging of the fine OA due to photochemical activity and transport. On the other hand, the presence of the cis-pinonic and pinic acids confirmed the SOA derived from biogenic sources. This is in line with the transport and stagnation events that predominated during spring and fall, respectively.

The emissions from vehicle exhausts are the most important, accounting for $64 \%$ of the identified $\mathrm{PM}_{2.5}$ emissions. By contrast, vegetative detritus and biomass burning were the lowest contributors, with barely $2.2 \%$ of the identified $\mathrm{PM}_{2.5}$ emissions.

Finally, a comparison with other studies indicates that the MMA exhibits similar concentrations patterns of the organic molecular markers identified in this study.

\section{The Supplement related to this article is available online at doi:10.5194/acp-16-953-2016-supplement.}

Acknowledgements. This work was supported by the Mexican National Council for Science and Technology (CONACYT) through grant number CB-2010-154122 and Tecnológico de Monterrey through grant number 0020CAT186. Y. Mancilla received additional support (a scholarship) through CONACYT. We appreciate the Integral System of Environmental Monitoring's support of the MMA during the field campaigns conducted in this study.

Edited by: W. Maenhaut

\section{References}

Abas, M. R. B. and Simoneit, B.: Composition of extractable organic matter of air particles from Malaysia: initial study, Atmos. Environ., 30, 2779-2793, 1996.

Abas, M. R. B., Rahman, N. A., Omar, N. Y. M. J., Maah, M. J., Samah, A. A., Oros, D. R., Otto, A., and Simoneit, B. R. T.: Organic composition of aerosol particulate matter during a haze episode in Kuala Lumpur, Malaysia, Atmos. Environ., 38, 42234241, doi:10.1016/j.atmosenv.2004.01.048, 2004.

Akyüz, M. and Çabuk, H.: Gas-particle partitioning and seasonal variation of polycyclic aromatic hydrocarbons in the atmosphere of Zonguldak, Turkey., Sci. Total Environ., 408, 5550-5558, 2010.

Alves, C., Pio, C., and Duarte, A.: Composition of extractable organic matter of air particles from rural and urban portuguese areas, Atmos. Environ., 35, 5485-5496, 2001. 
Alves, C., Oliveira, T., Pio, C., Silvestre, A. J. D., Fialho, P., Barata, F., and Legrand, M.: Characterisation of carbonaceous aerosols from the Azorean Island of Terceira, Atmos. Environ., 41, 13591373, 2007.

Alves, C. A., Vicente, A., Monteiro, C., Gonçalves, C., Evtyugina, M., and Pio, C.: Emission of trace gases and organic components in smoke particles from wildfire in a mixed-evergreen forest in Portugal, Sci. Total Environ., 409, 1466-1475, 2011.

Amador-Muñoz, O., Villalobos-Pietrini, R., Agapito-Nadales, M. C., Munive-Colín, Z., Hernández-Mena, L., Sánchez-Sandoval, M., Gómez-Arroyo, S., Bravo-Cabrera, J. L., and GuzmánRincón, J.: Solvent extracted organic matter and polycyclic aromatic hydrocarbons distributed in size-segregated airborne particles in a zone of México City: seasonal behavior and human exposure, Atmos. Environ., 44, 122-130, 2010.

Blanchard, C. L., Chow, J. C., Edgerton, E. S., Watson, J. G., Hidy, G. M., and Shaw, S.: Organic aerosols in the southeastern United States: speciated particulate carbon measurements from the SEARCH network 2006-2010, Atmos. Environ., 95, 327333, 2014

Brown, S. G., Herckes, P., Ashbaugh, L., Hannigan, M. P., Kreidenweis, S. M., and Collett Jr, J. L.: Characterization of organic aerosol in Big Bend National Park, Texas, Atmos. Environ., 36, 5807-5818, doi:10.1016/s1352-2310(02)00578-2, 2002.

Cass, G. R.: Organic molecular tracers for particulate air pollution sources, Trend. Anal. Chem., 17, 356-366, 1998.

Chen, L.-W. A., Watson, J. G., Chow, J. C., DuBois, D. W., and Herschberger, L.: $\mathrm{PM}_{2.5}$ source apportionment: reconciling receptor models for U. S. nonurban and urban long-term networks, J. Air Waste Manage. Assoc. 61, 1204-1217, 2011.

Chow, J. C., Watson, J. G., Lowenthal, D. H., Chen, L. W. A., Zielinska, B., Mazzoleni, L. R., and Magliano, K. L.: Evaluation of organic markers for chemical mass balance source apportionment at the Fresno Supersite, Atmos. Chem. Phys., 7, 17411754, doi:10.5194/acp-7-1741-2007, 2007.

Dvorská, A., Lammel, G., and Klánová, J.: Use of diagnostic ratios for studying source apportionment and reactivity of ambient polycyclic aromatic hydrocarbons over central Europe, Atmos. Environ., 45, 420-427, doi:10.1016/j.atmosenv.2010.09.063, 2011.

Duan, J., Tan, J., Cheng, D., Bi, X., Deng, W., Sheng, G., Fu, J., and Wong, M. H.: Sources and characteristics of carbonaceous aerosol in two largest cities in Pearl River Delta Region, China, Atmos. Environ., 41, 2895-2903, doi:10.1016/j.atmosenv.2006.12.017, 2007.

Eatough, D. J., Benner, C. L., Tang, H., Landon, V., Richards, G., Caka, F. M., Crawford, J., Lewis, E. A., Hansen, L. D., and Eatough, N. L.: The chemical composition of environmental tobacco smoke III. Identification of conservative tracers of environmental tobacco smoke, Environ. Int., 15, 19-28, 1989.

Feng, J., Hu, M., Chan, C. K., Lau, P. S., Fang, M., He, L., and Tang, $\mathrm{X}$.: A comparative study of the organic matter in $\mathrm{PM}_{2.5}$ from three chinese megacities in three different climatic zones, Atmos. Environ., 40, 3983-3994, doi:10.1016/j.atmosenv.2006.02.017, 2006.

Fraser, M. P. and Lakshmanan, K.: Using levoglucosan as a molecular marker for the long-range transport of biomass combustion aerosols, Environ. Sci. Technol., 34, 4560-4564, 2000.
Fraser, M. P., Cass, G. R., and Simoneit, B. R. T.: Particulate organic compounds emitted from motor vehicle exhaust and in the urban atmosphere, Atmos. Environ., 33, 2715-2724, 1999.

Fraser, M. P., Yue, Z. W., Tropp, R. J., Kohl, S. D., and Chow, J. C.: Molecular composition of organic fine particulate matter in Houston, TX, Atmos. Environ., 36, 5751-5758, doi:10.1016/s1352-2310(02)00725-2, 2002.

Fraser, M. P., Yue, Z. W., and Buzcu, B.: Source apportionment of fine particulate matter in Houston, TX, using organic molecular markers, Atmos. Environ., 37, 2117-2123, doi:10.1016/S13522310(03)00075-X, 2003.

Gelencsér, A.: Carbonaceous aerosol: atmospheric and oceanographic sciences library, Springer Publications, Dordrecht, the Netherlands, 184-190, 2004.

Giri, B., Patel, K. S., Jaiswal, N. K., Sharma, S., Ambade, B., Wang, W., Simonich, S. L. M., and Simoneit, B. R. T.: Composition and sources of organic tracers in aerosol particles of industrial central India, Atmos. Res., 120-121, 312-324, 2013.

Gogou, A., Stratigakis, N., Kanakidou, M., and Stephanou, E. G.: Organic aerosols in eastern Mediterranean: components source reconciliation by using molecular markers and atmospheric back trajectories, Org. Geochem, 25, 79-96, doi:10.1016/S01466380(96)00105-2, 1996.

Gonçalves, C., Alves, C., Fernandes, A. P., Monteiro, C., Tarelho, L., Evtyugina, M., and Pio, C.: Organic compounds in $\mathrm{PM}_{2.5}$ emitted from fireplace and woodstove combustion of typical portuguese wood species, Atmos. Environ., 45, 4533-4545, 2011.

González-Santiago, O.: Determinación del contenido de PAH's en partículas $\mathrm{PM}_{2.5}$ en una zona de alto tráfico vehicular y otra con potencial exposición industrial del Área Metropolitana de Monterrey, Ph.D. thesis, Facultad de Ciencias Químicas, Universidad Autónoma de Nuevo León (UANL), Mexico, 104 pp., 2009.

Guo, Z. G., Sheng, L. F., Feng, J. L., and Fang, M.: Seasonal variation of solvent extractable organic compounds in the aerosols in Qingdao, China, Atmos. Environ., 37, 1825-1834, 2003.

Harrad, S., Hassoun, S., Callén Romero, M. S., and Harrison, R. M.: Characterisation and source attribution of the semi-volatile organic content of atmospheric particles and associated vapour phase in Birmingham, UK, Atmos. Environ., 37, 4985-4991, 2003.

Henry, R. C., Lewis, C. W., Hopke, P. K., and Williamson, H. J.: Review of receptor model fundamentals, Atmos. Environ., 18, 1507-1515, 1984

Hildemann, L. M., Markowski, G. R., and Cass, G. R.: Chemical composition of emissions from urban sources of fine organic aerosol, Environ. Sci. Technol., 25, 744-759, 1991.

Hopke, P. K.: It is time to drop principal components analysis as a "receptor model", J. Atmos. Chem., 72, 127-128, 2015.

Huang, X.-F., He, L.-Y., Hu, M., and Zhang, Y.-H.: Annual variation of particulate organic compounds in $\mathrm{PM}_{2.5}$ in the urban atmosphere of Beijing, Atmos. Environ., 40, 2449-2458. doi:10.1016/j.atmosenv.2005.12.039, 2006.

INEGI: Estadísticas de vehículos de motor registrados en circulación, available at: http://www.inegi.org.mx/est/lista_cubos/ consulta.aspx?p=adm\&c=8 (last access: 22 January 2016), 2010.

INEGI: Censo de población y vivienda 2010, available at: www.inegi.org.mx/sistemas/consulta_resultados/iter2010.aspx? c=27329\&s=est (last access: 9 October 2015), 2011. 
Kalaitzoglou, M., Terzi, E., and Samara, C.: Patterns and sources of particle-phase aliphatic and polycyclic aromatic hydrocarbons in urban and rural sites of western Greece, Atmos. Environ., 38, 2545-2560, 2004.

Katsoyiannis, A., Sweetman, A. J., and Jones, K. C.: PAH molecular diagnostic ratios applied to atmospheric sources: a critical evaluation using two decades of source inventory and air concentration data from UK, Environ. Sci. Technol., 45, 8897-8906, 2011.

Kavouras, I. G., Stratigakis, N., and Stephanou, E. G.: Iso and anteiso-Alkanes: specific tracers of environmental tobacco smoke in indoor and outdoor particle-size distributed urban aerosols, Environ. Sci. Technol., 32, 1369-1377, 1998.

Kavouras, I. G., Lawrence, J., Koutrakis, P., Stephanou, E. G., Oyola, P.: Measurements of particulate aliphatic and polynuclear aromatic hydrocarbons in Santiago de Chile: source reconciliation and evaluation of sampling artifacts, Atmos. Environ., 33, 4977-4986, 1999.

Ke, L., Ding, X., Tanner, R. L., Schauer, J. J., and Zheng, M.: Source contributions to carbonaceous aerosols in the Tennessee Valley Region, Atmos. Environ., 41, 8898-8923, 2007.

Kelly, K. E., Kotchenruther, R., Kuprov, R., and Silcox, G. D.: Receptor model source attributions for Utah's Salt Lake City airshed and the impacts of wintertime secondary ammonium nitrate and ammonium chloride aerosol, J. Air Waste Manage. Assoc., 63, 575-590, 2013.

Kleeman, M. J., Riddle, S. G., Robert, M. A., Jakober, C. A., Fine, P. M., Hays, M. D., Schauer, J. J., and Hannigan, M. P.: Source apportionment of fine $\left(\mathrm{PM}_{1.8}\right)$ and ultrafine $\left(\mathrm{PM}_{0.1}\right)$ airborne particulate matter during a severe winter pollution episode, Environ. Sci. Technol., 43, 272-279, 2009.

Lee, S., Baumann, K., Schauer, J. J., Sheesley, R. J., Naeher, L. P., Meinardi, S., Blake, D. R., Edgerton, E. S., Russell, A. G., and Clements, M.: Gaseous and particulate emissions from prescribed burning in Georgia, Environ. Sci. Technol., 39, 90499056, 2005.

Li, M., McDow, S. R., Tollerud, D. J., and Mazurek, M. A.: Seasonal abundance of organic molecular markers in urban particulate matter from Philadelphia, PA, Atmos. Environ., 40, 22602273, doi:10.1016/j.atmosenv.2005.10.025, 2006.

Lin, L., Lee, M. L., and Eatough, D. J.: Review of recent advances in detection of organic markers in fine particulate matter and their use for source apportionment, J. Air Waste Manage. Assoc., 60, 3-25, 2010.

Mancilla, Y. and Mendoza, D.: A tunnel study to characterize $\mathrm{PM}_{2.5}$ emissions from gasoline-powered vehicles in Monterrey, Mexico, Atmos. Environ., 59, 449-460, 2012.

Mancilla, Y., Herckes, P., Fraser, M. P., and Mendoza, A.: Secondary organic aerosol contributions to $\mathrm{PM}_{2.5}$ in Monterrey, Mexico: Temporal and seasonal variation, Atmos. Res., 153, 348-359, 2015.

Marr, L. C., Grogan, L. A., Wöhrnschimmel, H., Molina, L. T., Molina, M. J., Smith, T. J., and Garshick, E.: Vehicle traffic as a source of particulate polycyclic aromatic hydrocarbon exposure in the Mexico City metropolitan area, Environ. Sci. Technol., 38, 2584-2592, doi:10.1021/es034962s, 2004.

Marr, L. C., Dzepina, K., Jimenez, J. L., Reisen, F., Bethel, H. L., Arey, J., Gaffney, J. S., Marley, N. A., Molina, L. T., and Molina, M. J.: Sources and transformations of particle-bound polycyclic aromatic hydrocarbons in Mexico City, Atmos. Chem. Phys., 6, 1733-1745, doi:10.5194/acp-6-1733-2006, 2006.

Martinez, M. A., Caballero, P., Carrillo, O., Mendoza, A., and Mejía, M. G.: Chemical characterization and factor analysis of $\mathrm{PM}_{2.5}$ in two sites of Monterrey, Mexico, J. Air Waste Manage. Assoc., 62, 817-827, 2012.

Mendoza, A., García, M. R., Vela, P., Lozano, D. F., and Allen, D.: Trace gases and particulate matter emissions from wildfires and agricultural burning in northeastern Mexico during the 2000 fire season, J. Air Waste Manage. Assoc., 55, 1797-1808, 2005.

Moffet, R. C., de Foy, B., Molina, L. T., Molina, M. J., and Prather, K. A.: Measurement of ambient aerosols in northern Mexico City by single particle mass spectrometry, Atmos. Chem. Phys., 8, 4499-4516, doi:10.5194/acp-8-4499-2008, 2008.

Noziere, B., Kalberer, M., Claeys, M., Allan, J., D’Anna, B., Decesari, S., Finessi, E., Glasius, M., Grgic, I., Hamilton, J. F., Hoffmann, T., Linuma, Y., Jaoui, M., Kahnt, A., Kampf, C. J., Kourtchev, I., Maenhaut, W., Marsden, N., Saarikoski, S., Schnelle-Kreis, J., Surratt, J. D., Szidat, Sönke, Szmigielski, R., and Wisthalder, A.: The molecular identification of organic compounds in the atmosphere: state of the art and challenges, Chem. Rev., 115, 3919-3983, 2015.

Oros, D. R. and Simoneit, B. R. T.: Identification and emission rates of molecular tracers in coal smoke particulate matter, Fuel, 79, 515-536, 2000.

Paatero, P.: Least squares formulation of robust non-negative factor analysis. Chemometr. Intell. Lab., 37, 23-35, 1997.

Park, S. S., Bae, M.-S., Schauer, J. J., Kim, Y. J., Yong Cho, S., and Jai Kim, S.: Molecular composition of $\mathrm{PM}_{2.5}$ organic aerosol measured at an urban site of Korea during the ACE-Asia campaign, Atmos. Environ., 40, 4182-4198, doi:10.1016/j.atmosenv.2006.02.012, 2006.

Peng, R. D., Bell, M. L., Geyh, A. S., McDermott, A., Zeger, S. L., Samet, J. M., and Dominici, F.: Emergency admissions for cardiovascular and respiratory diseases and the chemical composition of fine particle air pollution, Environ. Health Persp., 117, 957-963, 2009.

Perrone, M. G., Larsen, B. R., Ferrero, L., Sangiorgi, G., De Gennaro, G., Udisti, R., Zangrano, R., Gambaro, A., and Bolzacchini, E.: Source of high $\mathrm{PM}_{2.5}$ concentrations in Milan, northern Italy: Molecular marker data and CMB modelling, Sci. Total Environ., 414, 343-355, 2012.

Pietrogrande, M. C., Abbaszade, G., Schnelle-Kreis, J., Bacco, D., Mercuriali, M., and Zimmermann, R.: Seasonal variation and source estimation of organic compounds in urban aerosol of Augsburg, Germany, Environ. Pollut., 159, 1861-1868, 2011.

Plewka, A., Gnauk, T., Brüggemann, E., and Herrmann, H.: Biogenic contributions to the chemical composition of airborne particles in a coniferous forest in Germany, Atmos. Environ., 40, 103-115, doi:10.1016/j.atmosenv.2005.09.090, 2006.

Pope, C. A. III, Burnett, R. T., Thun, M. J., Calle, E. E., Krewski, D., Ito, K., and Thurston, G. D.: Lung cancer, cardiopulmonary mortality, and long-term exposure to fine particulate air pollution, J. Amer. Med. Assoc., 287, 1132-1141, 2002.

Qin, Y., Kim, E., and Hopke, P. K.: The concentrations and sources of $\mathrm{PM}_{2.5}$ in metropolitan New York City, Atmos. Environ., 40, S312-S332, 2006.

Ravindra, K., Sokhi, R., and Van Grieken, R.: Atmospheric polycyclic aromatic hydrocarbons: source attribution, emis- 
sion factors and regulation, Atmos. Environ., 42, 2895-2921, doi:10.1016/j.atmosenv.2007.12.010, 2008.

Reff, A., Eberly, S. I., and Bhave, P. V.: Receptor modeling of ambient particulate matter data using positive matrix factorization: review of existing methods, J. Air Waste Manage. Assoc., 57, 146-154, 2007.

Robinson, A. L., Subramanian, R., Donahue, N. M., BernardoBricker, A., and Rogge, W. F.: Source apportionment of molecular markers and organic aerosol. 2. Biomass smoke, Environ. Sci. Technol., 40, 7811-7819, doi:10.1021/es060782h, 2006a.

Robinson, A. L., Subramanian, R., Donahue, N. M., BernardoBricker, A., and Rogge, W. F.: Source apportionment of molecular markers and organic aerosol. 3. Food cooking emissions, Environ. Sci. Technol., 40, 7820-7827, doi:10.1021/es060781p, 2006b.

Rogge, W. F., Hildemann, L. M., Mazurek, M. A., Cass, G. R., and Simoneit, B. R. T.: Sources of fine organic aerosol. 1. Charbroilers and meat cooking operations, Environ. Sci. Technol., 25, 1112-1125, doi:10.1021/es00018a015, 1991.

Rogge, W. F., Hildemann, L. M., Mazurek, M. A., Cass, G. R., and Simoneit, B. R. T.: Sources of fine organic aerosol. 2. Noncatalyst and catalyst-equipped automobiles and Heavy-duty diesel trucks, Environ. Sci. Technol., 27, 636-651, 1993a.

Rogge, W. F., Hildemann, L. M., Mazurek, M. A., Cass, G. R., and Simoneit, B. R. T.: Sources of fine organic aerosol. 4. Particulate abrasion products from leaf surfaces of urban plants, Environ. Sci. Technol., 27, 2700-2711, doi:10.1021/es00049a008, 1993b.

Rogge, W. F., Hildemann, L. M., Mazurek, M. A., Cass, G. R., and Simoneit, B. R. T.: Sources of fine organic aerosol. 5. Natural gas home appliances, Environ. Sci. Technol., 27, 2736-2744, $1993 \mathrm{c}$.

Rogge, W. F., Hildemann, L. M., Mazurek, M. A., Cass, G. R. and Simoneit, B. R. T.: Sources of fine organic aerosol. 6. Cigarette smoke in the urban atmosphere, Environ. Sci. Technol., 28, 1375-1388, 1994.

Rogge, W. F., Hildemann, L. M., Mazurek, M. A., Cass, G. R., and Simoneit, B. R. T.: Sources of fine organic aerosol. 8. Boilers burning No. 2 distillate fuel oil, Environ. Sci. Technol., 31, 27312737, 1997.

Schantz, M., Poster, D., Kucklick, J., Wise, S., McDow, S., and Lewtas, J.: NISTIR 7303, Intercomparison program for organic speciation in $\mathrm{PM}_{2.5}$ air particulate matter: description and results for tiral III. NIST, 1-250, 2005.

Schauer, J. J. and Cass, G. R.: Source apportionment and particlephase air pollutants using organic compounds as tracers, Environ. Sci. Technol., 34, 1821-1832, 2000.

Schauer, J. J., Rogge, W. F., Hildemann, L. M., Mazurek, M. A., Cass, G. R., and Simoneit, B. R. T.: Source apportionment of airborne particulate matter using organic compounds as tracers, Atmos. Environ., 30, 3837-3855, 1996.

Schauer, J. J., Kleeman, M. J., Cass, G. R., and Simoneit, B. R. T.: Measurement of Emissions from Air Pollution Sources. 1. C1 through C29 organic compounds from meat charbroiling, Environ. Sci. Technol., 33, 1566-1577, 1999.

Schauer, J. J., Kleeman, M. J., Cass, G. R., and Simoneit, B. R. T.: Measurement of Emissions from Air Pollution Sources. 3. C1-C29 Organic Compounds from Fireplace Combustion of Wood, Environ, Sci. Technol., 35, 1716-1728, doi:10.1021/es001331e, 2001a.
Schauer, J. J., Kleeman, M. J., Cass, G. R., and Simoneit, B. R. T.: Measurement of Emissions from Air Pollution Sources. 4. C1-C27 Organic Compounds from Cooking with Seed Oils, Environ. Sci. Technol., 36, 567-575, doi:10.1021/es002053m, 2001b.

Schauer, J. J., Kleeman, M. J., Cass, G. R., and Simoneit, B. R. T.: Measurement of Emissions from Air Pollution Sources. 5. C1-C32 Organic Compounds from GasolinePowered Motor Vehicles, Environ, Sci. Technol., 36, 1169-1180, doi:10.1021/es0108077, 2002.

Schneidemesser, E. von., Schauer, J. J., Hagler, G. S. W., and Bergin, M.: Concentrations and sources of carbonaceous aerosol in the atmosphere of Summit, Greenland, Atmos. Environ., 43, 4155-4162, 2009.

Schnelle-Kreis, J., Sklorz, M., Peters, A., Cyrys, J., and Zimmermann, R.: Analysis of particle-associated semi-volatile aromatic and aliphatic hydrocarbons in urban particulate matter on a daily basis, Atmos. Environ., 39, 7702-7714, 2005.

SEDESOL, INEGI \& CONAPO.: Delimitación de las zonas metropolitanas en México 2005, México, 38 pp., 2007.

SENER: Prospectiva del sector eléctrico 2013-2027, 1-230, available at: http://www.smartgridmexico. org/site/es/documentos/documentos-rectores-sener/ 2-prospectiva-del-sector-electrico-2013-2027?format=html (last access: 21 January 2016), 2013.

Sheesley, R. J., Schauer, J. J., Bean, E., and Kenski, D.: Trends in secondary organic aerosol at a remote site in Michigan's upper peninsula, Environ. Sci. Technol., 38, 6941-6500, 2004.

SIEM: Secretaría de economía, estadísticas, available at: http: //www.siem.gob.mx/siem/portal/estadisticas/xmun.asp?edo=19, 2016.

Simoneit, B. R. T.: Application of molecular Mmarker analysis to vehicular exhaust for source reconciliations, Int. J. Environ. An. Ch., 22, 203-233, 1985.

Simoneit, B. R. T.: Characterization of organic-constituents in aerosols in relation to their origin and transport - a review, Int. J Environ. An. Ch., 23, 207-237, 1986.

Simoneit, B. R. T.: A review of biomarker compounds as source indicators and tracers for air pollution, Environ. Sci. Pollut. R. 6, 159-169, 1999.

Simoneit, B. R. T. and Mazurek, M. A.: Organic matter of the troposphere-II. Natural background of biogenic lipid matter in aerosols over the rural western United States, Atmos. Environ., 16, 2139-2159, 1982.

Simoneit, B. R. T. and Mazurek, M. A.: Organic tracers in ambient aerosols and rain, Aerosol Sci. Tech., 10, 267-291, 1989.

Simoneit, B. R. T., Cardoso, J. N., and Robinson, N.: An assessment of the origin and composition of higher molecular weight organic matter in aerosols over Amazonia, Chemosphere, 21, 1285-1301, 1990.

Simoneit, B. R. T, Sheng G. Y., Chen, X. J., Fu, J. M., Zhang, J., and $\mathrm{Xu}, \mathrm{Y}$. P.: Molecular marker study of extractable organicmatter in aerosols from urban areas of China. Atmos. Environ. 25, 2111-2129, 1991.

Simoneit, B. R. T., Kobayashi, M., Mochida, M., Kawamura, K., Lee, M., Lim, H.-J., Turpin, B., and Komazaki, Y.: Composition and major sources of organic compounds of aerosol particulate matter sampled during the ACE-Asia campaign, J. Geophys Res-Atmos., 109, 1-22, doi:10.1029/2004JD004598, 2004. 
Simoneit, B. R. T., Medeiros, O. M., and Didyk, B. M.: Combustion products of plastics as indicators for refuse burning in the atmosphere, Environ. Sci. Technol., 39, 6961-6970, 2005.

Sklorz, M., Schnelle-Kreis, J., Liu, Y., Orasche, J., and Zimmermann, R.: Daytime resolved analysis of polycyclic aromatic hydrocarbons in urban aerosol samples-Impact of sources and meteorological conditions, Chemosphere, 67, 934-943, 2007.

Spurny, K. R.: Aerosol chemistry and its environmental effects, in: Aerosol Chemical Processes in the Environment, edited by: Spurny, K. R., Florida, Lewis, 3-21, 2000.

SRM 1649a: Urban Dust/Organics, National Institute of Standards and Technology, US Department of Commerce: Gaithersburg, MD, 6 December 2007.

SRM 1649b: Urban Dust/Organics, National Institute of Standards and Technology, US Department of Commerce: Gaithersburg, MD, 23 February 2009.

Standley, L. J. and Simoneit, B. R. T.: Characterization of extractable plant wax, resin, and thermally matured components in smoke particles from prescribed burns, Environ. Sci. Technol., 21, 163-169, 1987.

Stone, E. A., Snyder, D. C., Sheesley, R. J., Sullivan, A. P., Weber, R. J., and Schauer, J. J.: Source apportionment of fine organic aerosol in Mexico City during the MILAGRO experiment 2006, Atmos. Chem. Phys., 8, 1249-1259, doi:10.5194/acp-81249-2008, 2008.

Tobiszewski, M. and Namieśnik, J.: PAH diagnostic ratios for the identification of pollution emission sources, Environ. Pollut., 162, 110-119, doi:10.1016/j.envpol.2011.10.025, 2012.

Tsapakis, M., Lagoudaki, E., Stephanou, E. G., Kavouras, I. G., Koutrakis, P., Oyola, P., and von Baer, D.: The composition and sources of $\mathrm{PM}_{2.5}$ organic aerosol in two urban areas of Chile, Atmos. Environ., 36, 3851-3863, doi:10.1016/s13522310(02)00269-8, 2002.

Upadhyay, N., Clements, A., Fraser, M., and Herckes, P.: Chemical speciation of $\mathrm{PM}_{2.5}$ and PM10 in south Phoenix, AZ, J. Air Waste Manage. Assoc., 61, 302-310, 2011.

Viana, M., Chi, X., Maenhaut, W., Querol, X., Alastuey, A., Mikuška, P., and Večeřa, Z.: Organic an elemental carbon concentrations in carbonaceous aerosols during summer and winter sampling campaigns in Barcelona, Spain, Atmos. Environ., 40, 2180-2193, 2006.

Viana, M., Kuhlbusch, T. A. J., Querol, X., Alastuey, A., Harrison, R. M., Hopke, P. K., Winiwarter, W., Vallius, M., Szidat, S., Prévôt, A. S. H., Hueglin, C., Bloemen, H., Wåhlin, P., Vecchi. R., Miranda, A. I., Kasper-Giebl, A., Maenhaut, W., and Hitzenberger. R.: Source apportionment of particulate matter in Europe: A review of methods and results, J. Aerosol Sci., 39, 827-849, 2008.

Villalobos, A. M., Amonov, M. O., Shafer, M. M., Devi, J. J., Gupta, T., Tripathi, S. N., Rana, K. S., Mckenzie, M., Bergin, M. H., Schauer, J. J.: Source apportionment of carbonaceous fine particulate matter $\left(\mathrm{PM}_{2.5}\right)$ in two contrasting cities across the IndoGangetic Plain, Atmos. Pollut. Res., 6, 398-405, 2015.

Wang, G. and Kawamura, K.: Molecular characteristics of urban organic aerosols from Nanjing: a case study of a mega-city in China, Environ. Sci. Technol., 39, 7430-7438, 2005.
Wang, G., Kawamura, K., Lee, S., Ho, K., and Cao, J.: Molecular, seasonal, and spatial distributions of organic aerosols from fourteen Chinese cities, Environ. Sci. Technol., 40, 4619-4625, 2006.

Watson, J. G., Chen, L.-W. A., Chow, J. C., Doraiswamy, P., and Lowenthal, D. H.: Source apportionment: Findings from the U. S. supersites program, J. Air Waste Manage. Assoc., 58, 265288, 2008.

Watson, J. G, Chow, J. C., Lowenthal, D. H., Chen, L.-W. A., Shaw, S., Edgerton, E. S., and Blanchard, C. L.: $\mathrm{PM}_{2.5}$ source apportionment with organic markers in the southeastern aerosol research and characterization (SEARCH) study, J. Air Waste Manage. Assoc., 65, 1104-1118, 2015.

Wold, S., Sjöström, M., and Eriksson, L.: PLS-regression: a basic tool of chemometrics, Chemometr. Intell. Lab., 58, 109-130, 2001.

Yin, J., Harrison, R. M., Chen, Q., Rutter, A., and Schauer, J. J.: Source apportionment of fine particles at urban background and rural sites in the UK atmosphere, Atmos. Environ., 44, 841-851, 2010.

Yokelson, R. J., Urbanski, S. P., Atlas, E. L., Toohey, D. W., Alvarado, E. C., Crounse, J. D., Wennberg, P. O., Fisher, M. E., Wold, C. E., Campos, T. L., Adachi, K., Buseck, P. R., and Hao, W. M.: Emissions from forest fires near Mexico City, Atmos. Chem. Phys., 7, 5569-5584, doi:10.5194/acp-7-5569-2007, 2007.

Young, L.-H. and Wang, C.-S.: Characterization of $n$-alkanes in $\mathrm{PM}_{2.5}$ of the Taipei aerosol, Atmos. Environ., 36, 477-482, doi:10.1016/s1352-2310(01)00298-9, 2002.

Yue, Z. and Fraser, M. P.: Polar organic compounds measured in fine particulate matter during TexAQS 2000, Atmos. Environ., 38, 3253-3261, 2004.

Yunker, M. B., Macdonald, R. W., Vingarzan, R., Mitchell, R. H., Goyette, D., and Sylvestre, S.: PAHs in the Fraser River basin: a critical appraisal of PAH ratios as indicators of PAH source and composition, Org. Geochem., 33, 489-515, 2002.

Zhang, X. L., Tao, S., Liu, W. X., Yang, Y., Zuo, Q., and Liu, Z.: Source diagnostic of polycyclic aromatic hydrocarbons based on species ratios: a multimedia approach, Environ. Sci. Technol., 39, 9109-9114, 2005.

Zheng, M., Cass, G. R., Ke, L., Wang, F., Schauer, J. J., Edgerton, E. S., and Russell, A. G.: Source apportionment of daily fine particulate matter at Jefferson Street, Atlanta, GA, during summer and winter, J. Air Waste Manage. Assoc., 57, 228-242, 2015.

Zheng, M., Cass, G. R., Schauer, J. J., and Edgerton, E. S.: Source apportionment of $\mathrm{PM}_{2.5}$ in the southeastern United States using solvent-extractable organic compounds as tracers, Environ. Sci. Technol., 36, 2361-2371, 2002.

Zheng, M., Salmon, L. G., Schauer, J. J., Zeng, L., Kiang, C. S., Zhang, Y., and Cass, G. R. Seasonal trends in $\mathrm{PM}_{2.5}$ source contributions in Beijing, China, Atmos. Environ., 39, 3967-3976, 2005.

Zurita, O.: Guía de árboles y otras plantas nativas en la zona metropolitana de Monterrey, Fondo Editorial de Nuevo León, ISBN: 978-607-7577-15-7, 82 pp., 2009. 